\section{Theory of Polarographic Limiting Current -Kinetic Current I.}

\author{
Mitsugi Senda \\ Department of Agricultural Chemistry, \\ Kyoto University, Kyoto, Japan
}

ポーラログラフィーの理論はこて十年間程の

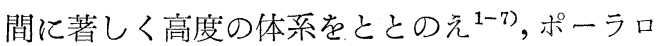
グラフ法による電解反応それ自体の定量的な研 究も多数報告されるようになつて来た，以下著 者の理解した範国に扣いて限界電流の理論の最 近の進歩を紹介するとともに，二三の考察を加 えてみたい，限界電流のうち限界拡散電流につ いては，すでに本誌上でも Stackelberg8) の明 解な綜説があるのでこてでは簡単にふれるにと ぞめ，主として Kinetic Current について述心 る，理論の紹介としては電流一電圧曲線を含め て紹介した方がより明確であるとも思われる が，乙れについてはまた別に本誌上に紹介され るのを期待したい.

\section{$\S 1$. 限 界 電 流}

酸化体 $\mathrm{O} x$ が $n$ ケの電子をとつて，還元体 Red に変化する反応，

$$
\mathrm{Ox}+\mathrm{ne}^{-}=\mathrm{Red}
$$

を考える。電解電流の大きさは Faraday の法 則を通して電解反応の速度を直接示す。云うま でもなく電気分解反応は界面反応であるから電 解電流の大きさ，即占反応速度は電極電位と共 に，また反応物質の電極界面への，及び界面か らの移動過程によつても大きく左右される，と くに限界電流が得られる範囲では実際上この界 面への移動過程によつてのみその電流值は規定 される。限界電流とは云うまでもなく“波高” に対応するものである，加電圧を徐々に増加し ていくと電解電流值はその実験法及び条件で䙺 定される一定の極限值认近づき，観祭電極の電 位をそれ以上増加しても電流值は殆んど变化し なくなる。乙の状態に達した笔位での電流を一

\section{ポーラログラフ限界電流の理論 反応電流について I.}<smiles>[3H][TlH]</smiles>

京都大学農学部農芸化学教室

般に限界電流と呼示。限界電流 $\left(i_{l}\right)$ の理論式 は上の極限值に対応するもので，電位を $\mathrm{E} て ゙$ 示 すと

$$
\frac{d \overline{\boldsymbol{i}}_{l}}{d E}=0
$$

で示され，一般に平均電流あるいは定常電流で 観察される。

限界電流の理論式は復極剂の溶液内での時間 的変化を示す微分方程式（Fickの第 2 则）をあ たえられた条件で解いて求められるが，その際 電極界面で直接電子をとる酸化体 Ox の浱度を 電解開始以後直ちに零と打く(還元反応の湯合, 以下特にことわらない限り還元反応について述 へ，酸化体及び還元体はともに溶液側にあると する)，電極表面を $x=0$ と扣き，電極面に垂 直に $x$ 軸をえらんで溶液側を正の方向にとり, 電解開始を $t=0$ とおくと，乙の境界条件は

$$
t>0, x=0: \quad{ }^{0} C_{0}=0
$$

で示される，乙こで ${ }^{0} C$ は電極界面での搌度を 示し，添字 $\mathrm{O}$ は $\mathrm{O} x$ を示す（添字 $\mathrm{R}$ で $\operatorname{Red}$ を示す， $C_{R}$ 等)。(3) 式は限界電流 ((2)式)に 対応する最も重要な境界条件である。

ポーラログラフィーでは普通充分多量の支持 兒解質の存在下で電解を行うから，復極剂の移 動は拡散（及び水銀滴の成長にともなつて起る 浴液の電極表面に対する相対運動）によつての み起る。乙の場合電流值は電極界面に打ける復 極剤の濃度勾配汃ら值ちに次式,

$$
i=n \mathrm{~F} q D_{o}\left(\frac{\partial C_{0}}{\partial x}\right)_{: c=0}
$$

によつて得られる。乙てで $\mathrm{F} は$ Faraday 定数, $q$ は電極表面積, $D_{0}$ は $\mathrm{O} x$ の拡散係数である. (4) 式は復極剂が電極界面で蓄積される等のと 
とがない限り，限界電流に限らず任意の電位で 成立ち，溶液内加ら单位時間に消失する $\mathrm{O} x$ の 量に $n \mathrm{~F}$ を乘じたものか電解電流值に等しいと 打くと，Fick の第 2 則から直接導かれる ${ }^{9,5)}$. 実測される限界電流值はてのようにして求め られた理論式で説明されるわけであるが，しか しこのととは限界電流が求められる電位で $\mathrm{O} x$ の界面濃度か湷際に（3）式で示すように零で あるととを意味するわけではない。てのような 電位では真の濃度勾配ぶ電解開始後極めて単時 間に(3)式を用いて得られる湍度勾配に近づき， 雨者は実際上一致すると見做しうるととによ $3^{1,2,10)}$. 水銀滴の成長の開始と共に電解刃゙始志 るわけであるから，開始直後は電標表面積 $q$ わ゙ 非常に小さく，特に一滴間の平均電流值を測定 する場合には，一般にこのごく初期の值は平均 值に大きくきいててないという事情にも注意す る必要怔ある。即ち (2) 式の限界電流か汗均あ るいは定常電流で観察され，また定毧されるわ けである。

\section{§2. 限界拡散電流 ${ }^{8)}$}

溶液内に存在する酸化体 $(\mathrm{Ox})$ か淔接電子を とつて還元される場合((1)式)を考える。電解開 始前溶液内いたるとて乃酸化体の濃度が様で ${ }^{*} C_{0}$ とし, 電解開始と共飞その界面 $(x=0)$ 旅 度がある一定值 ${ }^{0} C_{0}$ をとるとすると, 滴下極に 扣ける界面の濃度勾配は

$$
\left(\frac{\partial C_{0}}{\partial x}\right)_{x=0}=\frac{{ }^{*} C_{0}-{ }^{0} C_{o}}{\sqrt{\frac{3}{7} \pi D_{o} t}}
$$

で示される $5,7,11)$. 電極表面積は近似的に $t^{2 / 3} に$ 比例するので.

$$
i=n \mathrm{~F} q D_{0} \frac{{ }^{*} C_{o}-{ }^{0} C_{o}}{\sqrt{\frac{3}{7} \pi D_{o} t}}=\text { const } \cdot t^{1 / 6}
$$

となり，一滴間の僢閒電流值 $i$ は $t^{1 / 6}$ 飞比例 する。一滴閒の平均值は (6) 式の平均值で, 定 数を計算して結局,

$$
\bar{\imath}=607 n \sqrt{D_{o}} m^{2 / 3} \tau^{1 / 6}\left(* C_{0}-{ }^{0} C_{0}\right)
$$

になる。（7）式で濃度 $C$ を millimol/1， $D_{o}$ を $\mathrm{cm}^{2} \cdot \mathrm{sec}^{-1}$, 水銀の流出速度 $\mathrm{m}$ を $\mathrm{mg} \cdot \mathrm{sec}^{-1}$, 滴 下時間 $\tau$ を sec. であたえると平均電流值 $\boldsymbol{~}$ $\mu \mathrm{A}$ の单位で得られる。（5）式の分母は長さの 次元をもち(微分的な，あるいは瞬閒的な）“拡 散層の愿さ”と呼び，乙れを $\delta_{o}^{\prime}$ で示すと, (6) 式は

$$
i=n \mathrm{~F} q D_{0} \frac{{ }^{*} C_{o}-{ }^{0} C_{0}}{\delta_{o}^{\prime}}
$$

の形に表現される。平均電流も同様にして

$$
\bar{\imath}=n \mathrm{~F} q D_{0} \frac{{ }^{*} C_{0}-{ }^{0} C_{0}}{\delta_{o}}
$$

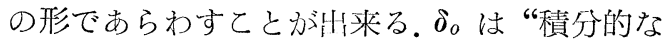
あるいは平均的な拡散阎の嬮さ”を示し, $\sqrt{D_{o} \tau}$ 程度の大きさの量である。束は平均表面積を示 す．以下 $\delta_{0}$ を広い意味で “Nernst の拡散層の 檿さ”と呼ぶ(添字 $\mathrm{o}$ は $\mathrm{Ox}$ のそれを示す). 更に

$$
\kappa_{o}=\frac{D_{o}}{\delta_{o}} \sim \sqrt{\frac{D_{o}}{\tau}}
$$

で定義される量はポーラログラフ法に打ける拡 散速度定数と呼ぶしとぶ卯来る量で4)，界面反 応の速度定数として $\mathrm{cm} / \mathrm{sec}$ の次元をもつてい る.

限界電流が得られる電位では ${ }^{*} C_{0} \gg{ }^{0} C_{0}^{0}$ で, (7) 式から（(3)に対応して）

$$
\overline{\boldsymbol{i}}_{d}=607 n \sqrt{\bar{D}_{o}} m^{2 / 3} \tau^{1 / 6 *} C_{o}
$$

即ち Ilkovic の限界拡散電流の式である。(11) 式は酸化体の浱度変化わ昿散（と滴の成長によ る波の相対運動) によつてのみ起るとして解い た場合の解であつて，その意味で限界拡散電流 あるいは簡単に拡散電流と呼ばれる。即ち電流 值は酸化体の電極表面への拡散によつてのみ規 定されている場合である（滴の成長の影響はて の場合本質的でない)，拡散層の厚さ $\delta$ あるい は速度定数にはこの場合に扣ける挙動を定性的 に表現する重要な因子である。電極現像に扣け る拡散，あるいは一般的にいつて物質移動過程 でもう一つ重要なととは電極の幾何学的形状で ある. Ilkovic 式は表面積 $q$ の上にある円柱状 空間から拡散が起るとして得られた式であるが 滴下極では電極は球形であり，溶液空間は電極 から放射状に広がつているから，Ilkovic 式に はこの滴表面の彎曲に対する補正 ${ }^{1,8)}$ が必要で ある。その補正式は 


$$
\begin{aligned}
\bar{i}_{d}^{\prime} & =607 n \sqrt{D} m^{2 / 3} \tau^{1 / 6} \\
& \left(1+\mathrm{A} \cdot D^{1 / 2} \cdot m^{-1 / 3} \tau^{1 /{ }^{\prime}}\right)
\end{aligned}
$$

であたえられる，括弧内第 2 項の $\mathrm{A}$ は 30 前後 の数值定数で, この項は $\delta_{0}$ と㵜将経 $\mathrm{R}$ と比 $\boldsymbol{\delta}_{o} / \mathrm{R}$ に対応する。限界拡散電流の詳紏及び文 献については文献 1)及び 8)を参照されたい.

支持電解質の量が充分多量でないと泳動の影 響があらわれ，酸化体のイオンの符男の正負に 応じて正あるいは負の Exaltation ${ }^{12)}$ が扎てる。 この間の事情は拡散層の愿さの変化として理解 される ${ }^{13,14)}$. 一般的に云つて母液中での復椣剂 の輸率が 1400 以下程度であれば理論的に充分 と思われる。最近麻田 ${ }^{15)}$ はこの間の事情を詳細 に検討して理論と実験との満足すべき一致を得 た.

\section{$\S 3$. 反 応 電 流}

ここで反応電流 (Kinetic Current) とは電解 反応によつて電極近傍に扣ける復極剤の化等平 衡がみだされ，その限界電流の大きさがその化 学反応の速度によつても影響される場合を云 う。ポーラログラフィーで反応電流がとり上げ られたのは 1943 年頃 ${ }^{16,17)}$ からで，その後多数 の研究が発表され18), 溶液内に打ける迅速反応 の研究法の一つとして重要な方法となつた，反 応電流は大きく別けると次の二つになる。

(i ) 先行する化学反応飞よる反応電流

(ii) 後続する化学反応による反応電流

(i) の例で云うと，たとえば Glucose を水に 溶解さすと

$$
\text { ピラノーズ型戸アルデヒド型 }
$$

の平衡が成立していて，アルデヒド型の方がよ り陽の電位で還元される。乙の場合その相下変 化の速度がかなり速いので，電極表面でアルデ ヒド型が還元されて消失するにつれて, 界面近 傍で上の平衡が右に進み，アルデヒド型ぶ補給 され，從つてアルデヒド型の限界電流が得られ る電位での限界電流值はその母液内での平衡篦 度と（11）あるいは（12）式から期待されるよ りも大きな值となる ${ }^{19)}$. (ii) の型式のものは， たとえば水素ガスで飽和したコロイド状パラジ ウムの存在下での可逆陖化罡元色素のロイコ型

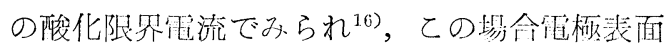

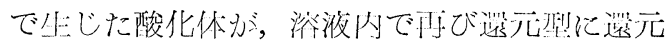
されるため，乙の反応による䘞紷分だけ限界 電流は限界搪散車流より大きくなる。主として 合柴国の硎究者の閒では（i）に刘して kinetic と称し，(ii）に対しては catalytic process と称 しているようであるが2， catalytic と云う萿葉 はむして所謂水素の接触還元波等代用いる心゙き であ万う。（ii）の型式は電解製造で注目されて いる閒接墁元の形式以刘応与る200所調接触波も 粪要な Kinetic Current の一つであるが,てし では詳細は省略する(例えばは1)，ただての種の 接触波あるいは蛩白波で波形心汕型をなすもの では多くの場合電解液の流動ふ起つていて ${ }^{22)}$, この事を考慮に入れる必要があり，メチレンブ ルー等で電流值の大きさと流動速度との閒に対 応関係を認めたと云う赫午もあることを絟介し て扣さたい233**) 拡散電流でない限界龟解とし てはこの外吸着波も貣要である刃，乙てでは省 略した。志た上の（i）及び（ii）共反応は溶湤 内で扎てるとした理諭式について紹介する。

\section{§4. 先行反応による反応電流}

1. 限界電流の式

この型式のものは最も簢监な場合,

$$
\begin{aligned}
& \mathrm{A} \underset{k_{1}^{\prime}}{\stackrel{k_{1}}{\rightleftharpoons}} \mathrm{Ox}, \mathrm{K}_{1}=\frac{k_{1}^{\prime}}{k_{1}} \\
& \mathrm{O} x \stackrel{n e}{\stackrel{n e}{\longrightarrow}} \mathrm{Red}
\end{aligned}
$$

で表現される*). $k_{1}, k_{1}{ }^{\prime}$ は一次反応の速度定数， $\mathrm{K}_{1}$ は平衡定数である。被逊元体の母液中での 全濐度 ${ }^{*} C$ は $\mathrm{A}$ と $\mathrm{O} x$ の和 ${ }^{*} C={ }^{*} C_{o}+{ }^{*} C_{\boldsymbol{A}}$ で あたえられ，母液内では ${ }^{*} C_{A} /{ }^{*} C_{o}=\mathrm{K}_{1}$ である。

$\mathrm{A}$ 及び $\mathrm{O} x$ の微分尔程式は次式で示され $3^{6,24)}$.

$$
\begin{aligned}
& \frac{\partial C_{A}}{\partial t}=\mathrm{D}_{\mathrm{A}} \frac{\partial^{2} C_{A}}{\partial x^{2}}-k_{1}\left(C_{A}-\mathrm{K}_{1} C_{0}\right) \\
& \frac{\partial C_{0}}{\partial t}=D_{o} \frac{\partial^{2} C_{o}}{\partial x^{2}}+k_{1}\left(C_{A}-\mathrm{K}_{1} C_{0}\right)
\end{aligned}
$$

*) Aにあたるものを electroinactive form, Ox あたるものを electroactive form と㭔ぶ。

**）たづし流速が䀝流做を规定していると断定出来 るわけではない。 
（16）式は嗸止平面雷極についての式であり,滴 の成長を腾虑すると右辺に $2 x / 3 t \cdot \partial \mathrm{C} / \partial x$ の貢が 加わる。しばらく考察を容易化するため(16)式 で諭を進める。 Ilkovic の袖正項を入れてもて こでは本質的な事情は変らない，境界条件は (16)式を用いて次の様にして得られる。即ち溶 液内加ら前位時間内に消失した全酸化体 $(\mathrm{A}+$ $\mathrm{O} x$ ）の量に $n \mathrm{~F}$ を㭋じたものは電流值 $i_{2}$ 飞等 しいから（界面 $x=0$ で蓄樍等がないとする, 座表は前節に同じ).

$$
\begin{aligned}
i_{l} & =n \mathrm{~F} q \int_{0}^{\infty}-\left(\frac{\partial C_{o}}{\partial t}+\frac{\partial C_{A}}{\partial t}\right) d x \\
& =n \mathrm{~F} q\left[D_{o}\left(\frac{\partial C_{0}}{\partial x}\right)_{x=0}+D_{A}\left(\frac{\partial C_{A}}{\partial x}\right)_{x=0}\right]
\end{aligned}
$$

同様にして，Aについてその全溶液内に打ける 単位時間内の減少量を計算すると，

$$
\begin{gathered}
-\int_{0}^{\infty} \frac{\partial C_{A}}{\partial t} d x=D_{A}\left(\frac{\partial C_{A}}{\partial x}\right)_{x=0} \\
-\int_{0}^{\infty} k_{1}\left(C_{A}-\mathrm{K}_{1} C_{o}\right) d x
\end{gathered}
$$

しかるに $(14,15)$ 式から，てのAの全溶液内で の減少は（14）式を通じてのみ起るから，

$$
-\int_{0}^{\infty} \frac{\partial C_{A}}{\partial t} d x=-\int_{0}^{\infty} k_{1}\left(C_{A}-\mathrm{K}_{1} C_{0}\right) d x
$$

ガ成立たねばならない，即ち

$$
t>0, x=0: \quad D_{A}\left(\frac{\partial C_{A}}{\partial x}\right)_{x=0}=0
$$

したがつて

$$
\frac{i}{n \mathrm{~F} q}=D_{o}\left(\frac{\partial C_{0}}{\partial x}\right)_{x=0}
$$

結局（17）式と（3）式

$$
t>0, x=0: \quad \quad{ }^{0} C_{o}=0
$$

を用いて（16）式を解き，得られる解から(18) 式を用いて電流が求められるととになる。（17） 式は $\mathrm{A}$ か淔接還元されないととを示す重要な境 界条件である。

第 1 節では浴液内に存在する酸化体か淔接電 子をとつて還元されるとした。しかし実際はこ のようなととが起つているという先験的な保証 はない.むしろ $(14,15)$ 式の機構等を考光るの が最も普通である。乙のような場合で,

(i ) $k_{1}, k_{1}{ }^{\prime}$ が非常に小さく, $l_{1} \tau \ll 1\left(l_{1}=k_{1}+\right.$ $k_{1}{ }^{\prime}, \tau$ は滴下時間）の場合には，一滴閒の間に
は（14）式の反応か実際上起らないと見做しう

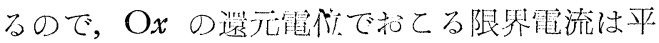
衡浱度 ${ }^{*} C_{o}$ と Ilkovic 式とできまり，その挙 動は第 2 節の拡散電流の理論式で説明される。 溶液内で打てる比較的打そい化学反応 ${ }^{25)}$ の追跡 をポーラログラフ汒で行う場合もての条件が必 要である.

(ii) $k_{1}, k_{1}^{\prime}$ か㵔しく大きく，漁液内では電 解開始後も実際上：(14）式は平衡状㑷にあると 若えられる場合, ての場合には $t>0$ で $x=0$ 亿 扣ける $\mathrm{A}$ の濃度も $\mathrm{O} x$ 同様 $C_{A}=0$ であると見 做しうる（ただし第 1 節参照）場合で， $\mathrm{O} x$ の 電解電位で得られる限界電流は実際上 Ilkovic 式で説明され， ${ }^{*} C={ }^{*} C_{\Delta}+{ }^{*} C_{0}$ 飞対応する拡散 電流になる。このような場合その限界電流の挙 動は溶液内の酸化体小淔接電子をとる場合のも のと区別がつかない，てのような例は多数の無 機錯塩その他でみとめられていて，A及び $\mathrm{O} x$ にあたる形がどのような形であるかを決定する には他の方法（交流電解法 ${ }^{26)}$ あるいは錯イオン での非可道波の解析 $\left.{ }^{27}, 28\right)$ その他)による。

（iii）（i）と（ii）の中間の場合で，反応電流

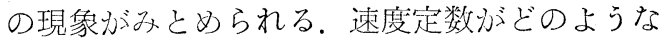
籁囲にあるときとのような現象小゙るとめられる かは実験法によつてきまるわけで，今の場合具 体的にはポーラログラフ限界電流の理論式によ つて答えられる。

この問題の筊密な解は静止平面電極について Koutecky Brdicka ${ }^{24)}$ によつて解かれ，Pyruvic acid 及び Phenylglyoxylic acid の反応電 流に適用されたが(その理論の詳しい紹介は文 献 6) 参照), Hanus ${ }^{29)}$ は後者について詳細に 検討した結果，理論と実験の差異を眀確にする と共に, その不供が主として滴の成長が考慮に 入れられてないととにあるととを明らかにし た，滴の成長を考慮に入れた場合の近似解は Koutecky ${ }^{30,31)}$ によつて示された。 それによる と

$$
\left(k_{1}+k_{1}^{\prime}\right) t=l_{1} t=\text { 非常に大きい. }
$$

と云う仮定を打くこと $D_{A}=D_{0}$ の場合の限界電 流 $\bar{\imath}_{l}$ は 


$$
\begin{aligned}
& \bar{i}_{l}=\bar{i}_{a} \cdot \frac{1}{1+1.12\left(\lambda_{l} \sqrt{\tau}\right)^{-1}} \\
& \lambda_{l}=\sqrt{l_{1}} / \mathrm{K}_{1}, D_{A}=D_{o}
\end{aligned}
$$

で近似的にあらわされる。乙こで $\overline{\boldsymbol{i}}_{d}$ は酸化体 の全濃度 ${ }^{*} C=C_{A}+{ }^{*} C_{0}$ を(11) 式に入れて得 られる限界拡散電流である。〔(20) 式は Koutecky と独立に導かれれ松田 ${ }^{32}$ )の近似式（誤差 1\%以下) であるが，Koutecky 等 ${ }^{31)}$ の式では 数值定数 1.12 か 1.13 になり, 雨者は一致す る. 数值は文献 ${ }^{31)}$ 参照コ（19a）の仮定が部さ れるのは第 1 節の終りにのべた事情によるもの で,あるいは

$$
l_{1} \tau \gg 1
$$

で表現出来るであろう， $l_{1} \tau$ が著しく大きく, $\left(\lambda_{l} \sqrt{\tau}\right)^{-1} \ll 1$ では $\bar{i}_{l} \rightarrow \bar{i}_{d}$ で, 前述 (ii) 亿対応 する.（19）式は一般的に云つて (iii) に刘応す るわけであるが，(21）式が示すように

$$
\mathrm{K}_{1} \gg 1
$$

ならば，即ち平衡がAの方へかたよつている場 合には反応電流があらわれることがわかる， $\mathrm{K}_{1}$ が著しく大きく， $\lambda_{2} \sqrt{\tau} \rightarrow 0$ では $\bar{\imath}_{2} / \bar{\imath}_{\boldsymbol{d}} \rightarrow 0\left(1 / \mathrm{K}_{1}\right.$ $\rightarrow 0)$ で， $\mathrm{O} x$ の電位では $\boldsymbol{i}_{\boldsymbol{a}}$ に比し著しくわず かの電流か流れることになる，滴の成長を考慮 に入れた一般的な解は未だえられていない.

\section{2. 反応層}

反応電流でよく用いられている “反応層”の 概念は上述の理論式が導かれているので，ある 意味では歴史的なものと云いうるが，多くの場 合てれは有效な考え方であることが示されて拀 $り^{33-35)}$ ，また反応電流が得られる場合の挙動を 理解する上に打いても重要であると思われる. 前項で述べたように得られている理論式は実際 上 $\mathrm{K}_{1} \gg 1$ の場合に対応する。 以下本項では一 般に $D_{A}=D_{o}$ 及び (22) 式を仮定する. 即ち

$$
\begin{aligned}
& \lambda_{i}^{\prime} \sqrt{\tau}=\sqrt{k_{1}^{\prime} \tau} / \mathrm{K}_{1} \\
& D_{A}=D_{o}=D
\end{aligned}
$$

Wiesner 等 ${ }^{16,19,36)}$ は反応電流 $\overline{\boldsymbol{i}}_{k}$ (反応電流 による增加分, $\mathrm{K}_{1} \gg 1$ であるから実際上 $\bar{i}_{k}=\bar{i}_{l}$ ) は電極界面の $\mu$ なる厚さの㿉内に打ける $\mathrm{A} \rightarrow$

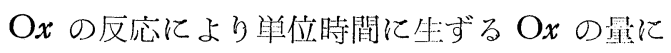
よつてきまると考えて

$$
\overline{\boldsymbol{i}}_{l}=n \mathrm{~F} \bar{q} \cdot \mu \cdot k_{1} \cdot{ }^{\circ}[\mathrm{A}]
$$

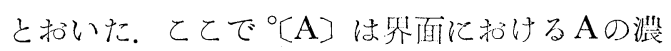

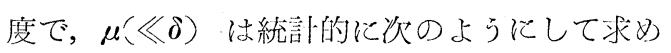
られた ${ }^{33,37)}$. 電極界面から $x^{\prime}$ の位置で $\mathrm{A} \rightarrow \mathrm{O} x$ の反応で生じた $\mathrm{O} x$ の分子を考えると，ての分 子の寿命 $\tau^{\prime}$ 闌に打ける拡散以よる平均移動趾! 離 $\Delta$ は Einstein 式 ${ }^{38)}$ により

$$
\Delta=\sqrt{2 D \tau^{\prime}}
$$

である， $\mathrm{O} x$ 分子の陦价を $\tau^{\prime}$ とすると，ての $\mathrm{O} x$ が䢦元されるには

$$
x^{\prime} \leqq \frac{1}{2} \Delta
$$

でなくてはならない. 1/2 は生じた $\mathrm{O} x$ の将 だけか電極界面に向つて移動するてとによる。 個々の $\mathrm{O} x$ 分子の寿命を平均寿命 $1 / k_{1}^{\prime}$ で打き かえると結局反応層の嬮さ $\mu_{W}$ は

$$
\mu_{W}=\sqrt{\frac{1}{2}} \sqrt{\frac{D}{k_{1}^{\prime}}} \geqq x^{\prime}
$$

であたえられる、Koutecky 等24) は (16) 式の 攸密解を導き, $l_{1} t \gg 1, \mathrm{~K}_{1} \gg 1$ の場合, その解 は

$$
i=n \mathrm{~F} q \cdot \mu_{\mathrm{K}} \cdot k_{1} \cdot C_{A}=D^{\prime}\left(\frac{\partial C_{A}}{\partial x}\right)_{x=0}
$$

による解に近似的に対応するととを示しだ. ここで

$$
\mu_{\mathrm{K}}=\sqrt{\frac{\bar{D}}{k_{1}^{\prime}}}
$$

である。即ち $\sqrt{2}$ 倍だけ異るが，(24)式があ る籁囲で罗当であるてとが示されたわけであ る. 実際 (24) 式と Ilkovic 式 ((7) 式),

$$
\bar{\imath}_{l}=n \mathbf{F} \bar{q}_{\kappa}\left({ }^{*} C_{A}-{ }^{\circ}[\mathrm{A}]\right)
$$

とを組合すと， $\mu=\mu_{\mathrm{K}}$ を用いて結局

$$
i_{l}=i_{d} \frac{1}{1+1.23\left(\lambda_{l}{ }^{\prime} \sqrt{\tau}\right)^{-1}}
$$

か導かれ ${ }^{16)} ，(20)$ 式で $\lambda_{l} \rightarrow \lambda_{l}^{\prime}$ とした式に対応 し, 雨者の相違は数值定数だけであり ${ }^{18)}$, 特に $\bar{\imath}_{l} \ll \overline{\boldsymbol{i}}_{a}$ であるときは

$$
\overline{\boldsymbol{i}}_{k}=n \mathrm{~F} \bar{q} \cdot \mu_{\mathrm{K}} \cdot k_{1} \cdot{ }^{*} C_{\boldsymbol{A}}
$$

となる。また（28）式の棌仂ら明らかなよう に $\lambda i{ }^{\prime} \sqrt{\tau}$ の意味は

*) (26) 式では反応首と溶液との界面を $x=0$ 亿え らんである。 


$$
\lambda_{i}^{\prime} \sqrt{\tau} \simeq \frac{\mu_{K} k_{1}}{(\sqrt{D} / \sqrt{\tau})}
$$

で示され，(24)式の界面に打ける化学反忘速度 定数と（10）式で定義した拡散速度定数との比 であるととがわかる。即ち $\bar{i}_{l}$ の挙動はこの雨 者の比によつてきまる。

Koutecky ${ }^{30)}$ は (20) 式を導くに際し (19a) の仮定成立つとき，

$$
\varphi=C_{\boldsymbol{A}}-\mathrm{K}_{1} C_{o}
$$

で定義される量が電解開始後

$$
\varphi=[\varphi]_{x=0} \cdot e^{-\sqrt{\frac{l_{1}}{D}}}
$$

によつて近似忛来るとした，反応電流の過程は 最初平衡にあつた（14）式の反応小電解か治志 ると ${ }^{\circ} C_{0}=0$ となつて $x=0$ で办だされ，拡散 と反応によつて再び平衡状態に向つて進行して いく過程と見做すととが出来る， $\varphi$ はとの平衡 状態からのずれをあらわす拯数で，明らかに $x=0$ で最も大きい（(31) 式）， $l_{1}$ 少著しく大き ければ溶液内 $(x>0)$ では $\varphi \rightarrow 0$ であり, ${ }^{0} C_{A} \rightarrow 0$ 即ち前項 1 でのべた（ii）飞対応する。（31）式 の指数中 $\sqrt{l_{1} / D}$ の逆数,

$$
\mu_{\mathrm{K}}^{\prime}=\sqrt{\frac{D}{l_{1}}}=\sqrt{\frac{D}{k_{1}^{\prime}\left(1+1 / \mathrm{K}_{1}\right)}}
$$

は $\mathrm{K}_{1} \gg 1$ で $\mu_{\mathrm{K}}((27)$ 式) に対応し，上述の“反 応層の厚さ”に対応する. 即ち $\mu_{\mathrm{K}} \approx \mu_{\mathrm{K}}^{\prime}$ は平衡 からのずれぶ $1 / e$ になる距離にあたる。志た

$$
\tau^{\prime \prime}=1 / l_{1}
$$

は（14）式の反応の緩和時間（均一反応に扔い て平衡からのずれが $t=0$ に扎けるその值の $1 / e$ になる時間）に対応し，乙の事は上述のWiesner による $\mu_{W}$ の導出と比較すると興味深い. （31）式を用いると境界条件から $C=C_{\Delta}+C_{0}$ と して

$$
\left(D \frac{\partial C_{0}}{\partial x}\right)_{x=0}=\frac{\sqrt{l_{1} D}}{\mathrm{~K}}{ }^{0} C
$$

が得られ，てれは $\mathrm{K}_{1} \gg 1$ で（32）式を考虑し て（26）あるいは（24）式付応する.

$$
D^{\prime}\left(\partial C_{0} / \partial x\right)_{x=0}=D(\partial C / \partial x)_{x=0} \quad \text { であるから, }
$$

（33）式の境界条件で $C$ についての Ilkovicの 微分方程式,

$$
\underset{-\frac{\partial C}{\partial t}}{-\frac{\partial^{2} C}{\partial x^{2}}}+\frac{2 x}{3 t} \frac{\partial C}{\partial x}
$$

を解くと $(20,21)$ 式の解が得られることになる。

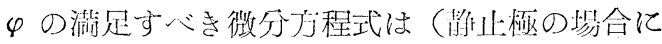
ついて㫪くと）（16）式から

$$
-\frac{\partial \varphi}{\partial t}=D \frac{\partial^{2} \varphi}{\partial x^{2}}-l \varphi
$$

で，(31）式が成立つには $l t$ が充分大きくてて の式の左辺が有辺にくらべて無視される必要が ある ${ }^{30)}$ 。実際 (31) 式を用いる近似解办ら，

$$
\begin{gathered}
\left|\frac{\partial \varphi}{\partial t} / l \varphi\right|=\frac{1}{\mathrm{~K}_{1^{2}}}\left(1-\frac{i_{d}}{i_{l}}\right) \\
\sim \frac{1}{\mathrm{~K}_{1} \sqrt{ } l_{1} t}
\end{gathered}
$$

であるととが示され， $\mathrm{K}_{1}$ が大きい程しの近似 がよいととがわかる。このととはまた厳密解か ら（26）式か㵾心れるための条件でもある ${ }^{24,6)}$. 反広買の意味を更に睤瞭にするために $x=\alpha \mu_{\mathrm{K}}{ }^{\prime}$ での湦度勾配を近似式（31）について求めると 特化

$$
x=\alpha \mu_{\mathrm{K}}^{\prime}, \quad l_{1} t / \alpha \gg \mathrm{K}_{1}
$$

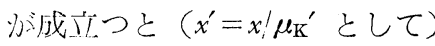

$$
\begin{aligned}
& D\left(\frac{\partial C_{o}}{\partial x}+\frac{\partial C_{A}}{\partial x}\right)_{x=\alpha}=D\left(\frac{\partial C_{0}}{\partial x}\right)_{x=0} \\
& D\left(\frac{\partial C_{0}}{\partial x}\right)_{x=\alpha}=D\left(\frac{\partial C_{0}}{\partial x}\right)_{x=0} \cdot-\frac{\mathrm{K}_{1}}{1+\mathrm{K}_{1}}\left(\frac{1}{\mathrm{~K}_{1}}+e^{-\alpha}\right) \\
& \mathrm{D}\left(\frac{\partial C_{\Delta}}{\partial x}\right)_{x=\alpha}=D\left(\frac{\partial C_{0}}{\partial x}\right)_{x=0} \frac{\mathrm{K}_{1}}{1+\mathrm{K}_{1}}\left(1-e^{-\alpha}\right)
\end{aligned}
$$

の関係が得られ，電極のごく近傍に扔いては一 種の定常状態が仮定され，反応電流に対応する 化学反応はこの層内で打てり， $\mathrm{K}_{1} \gg 1 ， x=\mu_{\mathrm{K}}^{\prime}$ とすると大体 $70 \%$ にあたる部分が渡層 $(0<x$ <的）で扣てる反応にもとづくことが示され

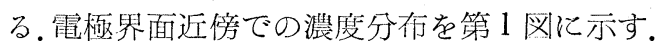
（网では $\mu$ を $\delta$ にくらへて大きく示し，また $C_{A}$ の方は $C_{0}$ に対し縮少して示した，破線は (24 a, b , 27) 式の取扱いに対する濃度分布の 模型で， $0<x<\mu_{K}$ で $C_{\boldsymbol{A}}$ は一定， $C_{0}$ は直線濃 度勾配を仮定すると， ${ }^{\mu} C_{o} / \mu_{K}={ }^{0} C_{A} / \mathrm{K}_{1} \cdot \mu_{K}=$ $k_{1} \cdot \mu_{K} \cdot{ }^{0} C_{A} / D=\left({ }^{*} C_{A}-{ }^{0} C_{A}\right) / \delta_{N}$ の関係市る。 $)$

反応首の概念を最初に導入したのは $\mathrm{A} . \mathrm{Eu}-$ cken である ${ }^{39)}$. 彼はてれと Nernst の拡散層 の概念とから定常電解に扣ける先行反応による 反応電流の理論式を導き，銀のシアン錯イオン 


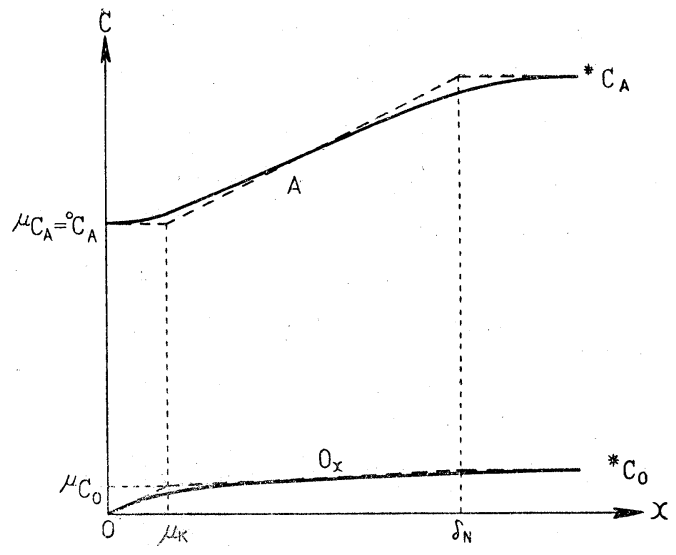

第 1 図，酸化体の濃度分布

$\delta_{\mathrm{N}}:$ Nernst の拡散層の厚さ， $\mu_{\mathrm{K}}$ : 反応酋の厚さ

の定常電解電流に対してその理論を適用した. この考え方はVetter 等 ${ }^{10)}$ にり更に一般的な 場合にまで拡張された，Eucken は電極界面に 拡散層にくらべてはるかにうすい厚さ $\mu_{\mathrm{E}}$ の反 応層 (Reaktionsraum) を考光，反応電流に対 応する反応はての層内で括てるとし， $0 \leq x<\mu_{\mathrm{E}}$ に打ける（16）の微分方程式の定常状態 $(\partial \mathrm{G} / \partial t$ =0)に打ける解を次の条件で求めた.

$$
\begin{aligned}
x= & \mu_{\mathrm{E}} ; \\
& D \frac{d C_{A}}{d x}=D\left(\frac{d C_{0}}{d x}\right)_{x=0}, D \frac{d C_{o}}{d x}=0 \\
x= & 0 ; \\
& D \frac{d C_{A}}{d x}=0, \\
0 & <x<\mu_{\mathrm{E}} ; \\
& C_{A}={ }^{0} C_{A}=\text { const. } \\
x \geqq \mu_{\mathrm{E}} ; & C_{A}-\mathrm{K}_{1} C_{0}=0
\end{aligned}
$$

てれから反应層内の $C_{0}$ の濃度勾配を求めると ${ }^{0} G_{0}=0$ として結局 $\mathrm{K}_{1} \gg 1$ に対応して

$$
D\left(\frac{d C}{d x}\right)_{x=0}=k_{1} \cdot \sqrt{\frac{D_{0}}{k_{1}^{\prime}}} C_{A}=D\left(\frac{d C_{A}}{d x}\right)_{x=\mu}
$$

が得られ，(24a，b)あるいは（26)式に対応する。 この事情は（30３5）式と（36）式の条件との 明瞭な対応から容易に理解される. Eucken の $\mu_{\mathrm{E}}$ は $\mu_{\mathrm{K}}$ 等よりも幾分大きいととになるが,

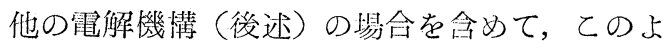

うにして導かれる(37)式に対応する式は $\mathrm{K}_{1} \gg 1$ に相当する条件を仮定すると Kontecky の方法 による近似解に一致し，更にこの方法は電流電 圧曲線の場合にも適用出来る事が示される ${ }^{34)}$.

（29）式の説明で $\mu k_{1}$ を界面での反応速度定 数と呼んだが，乙れは（24）式を形成的に表現 したもので，上述したように電流值を規定する ものはあくまで $x=0$ に打ける $\mathrm{O} x$ の濃度勾配 であり， $\mu k_{1}$ は等価的な界面速度定数である.反 応電流值に対応する反応は大部分反応層内で扔 こるから，問題になる速度定数は界面の近傍で のそれである、したがつて この反応は電極界面にある強い電場の影響をう けていることになり, 溶液内の速度定数と少し 意味刃゙異るととになる ${ }^{18,42)}$ との意味の限度とし てたとえば $10^{-7} \mathrm{~cm}<\mu$ とすると， $k_{1}^{\prime}$ は $10^{8}$ $\mathrm{sec}^{-1}$ 程度以下と云うととになる。

\section{3. 曲率の影響}

電㥛の曲率の影響は次のようにして半定量的 に説明される ${ }^{34)}$. (29) 式による $\lambda_{l} \sqrt{\tau}$ の物理 的意味から，(12)式による球の補正を考虑に入 れた拡散速度定数 $\quad \kappa \sim \sqrt{D}\left(1+\mathrm{A} \cdot D^{1 / 2} \cdot m^{-1 / 3}\right.$. $\left.\tau^{1 / 6}\right) / \sqrt{\tau}$ を用いると，

$$
\lambda_{l}^{\prime \prime}=\frac{\sqrt{ } l_{1}^{-}}{\mathrm{K}_{1}}\left(\frac{1}{1+\mathrm{A} \cdot D^{1 / 2} m^{-1 / 3} \tau^{1 / *}}\right)
$$

少得られる。即ち実測される $\overline{\boldsymbol{i}}_{l} / \overline{\boldsymbol{i}}_{\boldsymbol{a}}$ 汃ら求めた $l_{1}$ は球補正を行わないと幾分小さく見積られる ことになる. Koutecky 等の計算によると ${ }^{43}$

$$
\begin{gathered}
\frac{\bar{i}_{l}}{\bar{i}_{d}^{\prime}}=\frac{1}{1+1.12\left(\lambda_{l} \sqrt{\tau}\right)^{-1}}-z \cdot \mathrm{H}\left(\lambda_{l} \sqrt{\tau}\right) \\
z=50.4 D^{1 / 2} m^{-1 / s} \tau^{1 / 6}
\end{gathered}
$$

であたえられる，てこで $i_{d}^{\prime} は(12)$ 式による。 函数 $\mathrm{H}\left(\lambda_{2} \sqrt{\tau}\right)$ は数表にしておたえられている が，その意味は（20）式に（21") を代入した式 加ら $z$ が小さい場合近似的に

$$
\begin{aligned}
\frac{\overline{\boldsymbol{i}}_{e}}{\overline{\boldsymbol{i}}_{d}^{\prime}}= & \frac{1}{1+1.12\left(\lambda_{l} \sqrt{\tau}\right)^{-1}} \\
& A D^{1 / 2} m^{-1 / 3} \tau^{1 / 6} \frac{1.12\left(\lambda_{l} \sqrt{\tau}\right)^{-1}}{\left(1+1.12\left(\lambda_{l} \sqrt{\tau}\right)^{-1}\right)^{2}}
\end{aligned}
$$

を得ることから明嘹である。実際 $\mathrm{H}\left(\lambda_{B} V \bar{\tau}\right)$ は $\overline{\boldsymbol{i}}_{l} / \overline{\boldsymbol{i}}_{d}$ が 0.6 附近で極大をとる囦数で, $\left(22^{\prime \prime}\right)$ は 
H の挙動をほメ゙定量的によく示している。(こ の場合A は 40 亿近い定数である).

Phenyglyoxylic acid の $\bar{i}_{l} / \bar{i}_{d}$ が水銀の流出 速度によつて変化するてとはすでに Hanus ${ }^{29)}$ によつて見出されている。 $\bar{i}_{l} / \bar{z}_{d}$ が小さくなれば 球補正は無視しうる. 更に碳密な意味では, 特 に $\overline{\boldsymbol{i}}_{l} / \overline{\boldsymbol{z}}_{\boldsymbol{a}}$ か 1 亿近い場合, 稀薄効果等 $\left.{ }^{8}\right)$ の考虑 も必要であ万う。

\section{4. 反応電流の挙動}

反応電流と拡撒電流との区別法として普通限 界電流の温度効果，及び水銀溜の高さを変える ことによる変化が用いられる。

（i）温度效果 限界拡散電流の温度效果は よくしられているように常温附近で 1 〜 $\%$ で ある. ての温度效果は主として拡散係数の温度 効果にもとづくもので,

$$
\frac{1}{\bar{i}_{d}} \cdot \frac{d \bar{i}_{d}}{d \mathrm{~T}} \fallingdotseq \frac{1}{2} \cdot\left(\frac{d D}{D d \mathrm{~T}}-\frac{1}{\eta} \cdot \frac{d \eta}{d \mathrm{~T}}\right)
$$

こてでクは水銀の粘度である。拡散係数の温度 効果は一般によい近似で

$$
D=\text { const } \cdot \exp \left(-\frac{\mathrm{E}_{\mathrm{D}}}{\mathrm{RT}^{-}}\right)
$$

で示される ${ }^{44)}$. 水銀の粘度についても同様の関 係が認められ， $\mathrm{E}_{\eta} \sim-0.6 \mathrm{Kcal}$ 程度である。 したがつて

$$
\frac{d \ln \bar{z}_{a}}{d(1 / \mathrm{T})}=-\frac{1}{2 \mathrm{R}}-\left(\mathrm{E}_{\mathrm{D}}-\mathrm{E}_{\eta}\right)
$$

$\mathrm{E}_{\mathrm{D}}$ は数 $\mathrm{Kcal}$ 程度の大きさである. (2) 式 で $\lambda_{2} \sqrt{\tau}$ が充分小さい場合を考え，乙の時の 電流を $\bar{\imath}_{k}$ で示すと

$$
\bar{i}_{k} \simeq \frac{\bar{i}_{d}}{1.23} \cdot \lambda_{l} \sqrt{\tau}
$$

となり (29 式脚註参照),

$$
\frac{1}{\overline{\boldsymbol{i}}_{k}} \frac{d \overline{\boldsymbol{i}}_{k}}{d \mathrm{~T}} \simeq \frac{1}{2} \cdot \frac{1}{D} \cdot \frac{d D}{d t}+\frac{1}{\lambda_{l}} \cdot \frac{d \lambda_{l}}{d t}
$$

もしくは

$$
\frac{d \ln \bar{i}_{k}}{d(\bar{l} / \mathrm{T})} \simeq-\frac{1}{2 \mathrm{R}}\left(\mathrm{E}_{\mathrm{D}}+2 \mathrm{E}_{\lambda}\right)
$$

を得る. 以上の関係から $\mathrm{E}_{\lambda}>0$ であれば（そ しててのととは一般に期待される）反応電流の 温度効果は拡散電流のそれより大きく，乙の関 係は一般にみとめられている事実である。
温度效果は（23）式と（25）式の閒にあり，温 度と共に $\lambda_{l} \sqrt{\tau}$ が変化するから高温では (23) に低温では(25)に近づく,乙の関係及び $\left(23^{\prime}\right)$ 式 の関係は永田等 ${ }^{45)}$ の Isnicotinic acid の実験

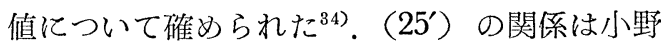
等によつて Alloxan その他の共䡉 Tricarbonyl 化合物について認められている ${ }^{46)}$.

(ii) 滴下時間による変化 限界電流が応 電流の性質をもつているかどうかを確める最も 基本的な方法は，乙の滴下時間による方法であ る。乙れはポーラログラフ法が時間的に変化す る電解電流，非定常電流を取扱つているととに よる。したがつて電流一時間曲線を観測する方 が，乙の検討法よりもより本質的な方法である が，高い再現性をもつ滴下電極を介してての時 間的変化は平均電流の滴下時間による変化に抏 きかえられる，限界拡散電流で云えば，電流密 度 $\sim t^{-1 / 2}$, 一滴間の電流 $\sim t^{1 / 6}$, 平均電流 $\sim \tau^{1 / 6}$ の関係がある。

䍃知の上うに滴下時間 $て$ を変化さすには同一 の毛細管で水銀溜の高さHをかえて捛てない.

$$
\begin{aligned}
& m=m_{0} \cdot \mathrm{H} \\
& \tau=\tau_{0} / \mathrm{H}
\end{aligned}
$$

の関係を利用する，波高と $\sqrt{\mathrm{H}}$ の関係は(26) 式を用いて，(12)，(20)，(21") 式等からえら れその傾斜は次の式であたえられる.

$$
\begin{gathered}
\frac{1}{\bar{i}_{d}} \cdot \frac{d \bar{i}_{d}}{d \sqrt{\mathrm{H}}}=\frac{1}{\sqrt{\mathrm{H}}} \cdot \frac{1}{(1+\alpha)} \\
\frac{1}{\bar{i}_{l}} \cdot \frac{d \bar{i}_{l}}{d \sqrt{\overline{\mathrm{H}}}}=\bar{l} \frac{1}{\sqrt{\mathrm{H}}} \cdot \frac{1}{(1+\alpha)} \cdot \\
\frac{1}{1+1.12\left(\lambda_{l}^{\prime \prime} \sqrt{\tau}\right)^{-1}}
\end{gathered}
$$

乙こで $\alpha$ は球補正係数 $\mathrm{A} V \overline{\mathrm{D}} m^{-1 / 3} \tau^{1 / 6}$ であ る. (即ち $\bar{i} \sim \sqrt{ } \overline{\mathrm{H}}$ 曲線の傾斜の度合は $\bar{i}_{l}$ の場 合 $i_{a}$ に比し小さくなる). 実祭上は $\sqrt{\mathrm{H}}$ をそ れ程大きく変化さすのでないのから， $\alpha$ はほぼ 定数とみなし得て普通 0.05 程度の值である. (27b) 式を用いると $n,{ }^{*} C, \sqrt{D}$ 等が確実にわ かつていなくても $\lambda_{l}$ 跨求めるてとが出来る. 球補正を行うには $V \bar{D}$ の大体の值で充分であ る. (27)の関係は無機イオンの $\bar{i}_{d}$ や Citrinin ${ }^{47)}$ の $\bar{i}_{d}$ 及び $\bar{i}_{l}$ につて認められた ${ }^{34)}$.な打ての 
種の検詩を行うには（26）式の関係を雄めてお く方が安全である。一般に(26a) はよく成立す るが，(26b）は毛細管によつてはあまりよく成 立たない場合もあるようである。このような場 合は $\bar{i}$ を $(m t)^{2 / 3}$ 等で割り， $\sqrt{\mathrm{H}}$ を $1 / \sqrt{ } \tau$ で 打きか壳ると（27）式は同様化成立する。度 電流が含志れているかどうかを検討するもつと もすぐれた方法の一つは（20）式から導かれる 次式によるものである ${ }^{48)}$.

$$
\sqrt{\tau} \bar{\imath}_{l}=-1.12 \cdot \frac{\bar{\imath}_{l}}{\lambda_{l}}+\sqrt{\tau} \bar{i}_{d}
$$

すなわち $\sqrt{ } \tau \bar{\imath}_{l} \sim \bar{l}_{l}$ 曲線を描けば負の傾斜をも つた直線 $\left(\sqrt{\tau} \overline{\boldsymbol{z}}_{d}\right.$ は (26) 式が成立つとHに関 せず一定）方得られ，乙の傾斜から $\lambda_{l}$ も求め られる，拡散電流ならばこの曲線は $\boldsymbol{\imath}_{l}$ 軸に平行 な線となる。これは $\bar{i}_{d}$ の検討に用いられている。

$$
\frac{\bar{i}_{a}}{\sqrt{ } \overline{\mathrm{H}}}=\text { const. } ; \sqrt{ } \bar{\tau}_{\tau} \bar{i}_{d}=\text { const. } \quad \text { (28b) }
$$

に刘応する。（28a）式はクロノポテンシオメト リーに扣ける[電流密度〕 $\times[\text { 遷移時間 }]^{1 / 2}$ 電流 密度曲線 ${ }^{2}$ に対応する。曲率の補正を考慮に入 れても， $\alpha$ はほぼ一定とみなしうるから $(28 \mathrm{a}, \mathrm{b})$ の関係は近似的に成立すると考元てよい.

$$
\lambda_{l} \sqrt{\tau} \text { が非常に小さく, } \bar{i}_{l} / \bar{z}_{d} \ll 1 \text { の場合の電 }
$$
流は

$$
\overline{\boldsymbol{i}}_{k}=1.23 \bar{i}_{a} \cdot \lambda_{l} \sqrt{\bar{\tau}}
$$

となり*)， $\overline{\boldsymbol{\imath}}_{k}$ は $\mathrm{m}^{2 / 3} \tau^{2 / 3}$ に比例し，Hに関せず 一定である。乙の場合は $\bar{i}_{d}$ が実測か計算でわ かつていないと $\lambda_{l}$ は求められない（20）式か ら得られる

$$
\frac{1}{\bar{i}_{l}}=\frac{1}{\bar{i}_{d}}+\frac{1}{\bar{i}_{d}} \cdot \frac{1.12}{\lambda_{l} \sqrt{\tau}}
$$

の関係 ${ }^{3 \bar{\jmath})}$ は $\bar{i}_{d} \sqrt{\tau}=$ 一定の条件で直接 $\lambda_{l}$ の性 質を明らかにするのに用いられている。

（iii） 反灾電流は拡散電流にくらべて表面活 性剂の影響を強くうけ，波高が著しく低下する 等の現象がいくつか見出されている ${ }^{95,96,35,46)}$. このととはまた界面活性剤の電㥛反応に及ばす 影響の研究の立場からも注目されている ${ }^{95-97)}$.

*) (20) 式から求めると数值定数は 1.12 亿なるが， これは (20) 式が $\bar{\imath}_{\ell} \sim 0.5 \bar{i}_{a}$ 附近でもつとも近 似が良いようにして求めた近似式であることに よる、いまの場合は (29) 式の方が近似がよく とれは結局 $\left(28^{\prime}\right)$ 式に対応する。
溶媒組成(水一アルコール) 亿早) にる大きな変化 もみとめられている。

\section{§5. 先行反応にょる反応電流の諸形式}

いろいろの反応機構についてその理論式が導 かれている。静止平面電極の場合はその㛜密解 が得られている例が多数ある ${ }^{24,49,50)}$ が, こてで は実際に適用されている滴の成長を考虑に入れ た式，すなわち Ilkovic の微分方程式から出発 して導かれた式について紹介する。乙の場合は いずれも前節 1 でのい゙た Koutecky の近似が用 いられている。 な打大多数の場合電流〜電王曲 線を含めて解があたえられている。以下酸化体 の全濃度を $C$ で，直接電子授受を行わない形を $\mathrm{A}_{1}, \mathrm{~A}_{2}, \mathrm{~A}_{3} \cdots \cdots$ で示し，それぞれに対応する拡 散係数及び濃度を $D_{1}, D_{2}, \cdots \cdots$ 及び $C_{1}, C_{2} \cdots \cdots$ で示す.

1.

$$
\begin{aligned}
& \mathrm{A}_{1} \underset{k_{1}^{\prime}}{\stackrel{k_{1}}{\rightleftharpoons}} \mathrm{O} x, \quad \mathrm{~K}_{1}=\frac{k_{1}^{\prime}}{k_{1}} \\
& \mathrm{O} x \stackrel{n e}{\longrightarrow} \operatorname{Red}
\end{aligned}
$$

この機構については $D_{1}=D_{o}=D$ の場合につい ては前節で詳細にのべた。 Koutecky は更に $D_{0} \neq D_{1}$ にまで拡張して

$$
\begin{gathered}
\quad \frac{\bar{i}_{l}}{\overline{\boldsymbol{i}}_{d}}=\frac{1}{1+1.12\left(\lambda_{l} \sqrt{\tau} \mathrm{M}\right)^{-1}} \\
\overline{\boldsymbol{i}}_{d}=607 n \sqrt{\frac{D_{o}+\mathrm{K} D_{1}}{1+\mathrm{K}}} m^{2 / 3} \tau^{1 / 6} \cdot * C \\
\mathrm{M}=\frac{1}{D_{1}} \sqrt{\frac{D_{o}}{D_{1}}} \cdot \frac{D_{o}+\mathrm{K} D_{1}}{1+\mathrm{K}}
\end{gathered}
$$

を導いている。

$$
\lambda_{l}=\frac{\sqrt{l_{1}}}{\mathrm{~K}_{1}} \sim \sqrt{\frac{k_{1}}{\mathrm{~K}_{1}}}, \quad \mathrm{~K}_{1} \gg 1
$$

この形式として最も多数研究されているのは 有機一塩基酸の還元波についてである ${ }^{18,45,52,53)}$.

$$
\mathrm{A}^{-}+\mathrm{H}^{+} \underset{k_{d}}{\stackrel{k_{r}}{\rightleftharpoons}} \mathrm{AH}
$$

$$
\mathrm{AH} \stackrel{n e}{\longrightarrow} \mathrm{Red}
$$

充分緩衝された溶液で電解を行えば，酸の再結 合反応は一次反応として取扱うととが出来, (I) の機構を適用计来る。乙の場合 $k_{1}=k_{r}\left[\mathrm{H}^{+}\right]$, $k_{\perp}{ }^{\prime}=k_{d}, \mathrm{~K}_{1}=\mathrm{K}_{\Lambda} /\left[\mathrm{H}^{+}\right]$で打きかえると $\left(\mathrm{K}_{\mathrm{A}}\right.$ は 
酸の解離定数 $) . \quad \lambda_{l}=\sqrt{k_{d}} / \mathrm{K}_{\mathrm{A}} \cdot\left[\mathrm{H}^{+} 〕\right.$ となり, $\overline{\boldsymbol{i}}_{l} / \overline{\boldsymbol{z}}_{\boldsymbol{d}}$ 曲線は解離曲線と同じ形になり $\bar{i}_{l} / \overline{\boldsymbol{i}}_{d}=0.5$ になるときの $\mathrm{pH}$ を $\mathrm{pK}^{\prime}$ で示すと，(20)式を 用いて， $\lambda_{l} \sqrt{\tau}=1.12$ から，

$$
\mathrm{pK}^{\prime}=\mathrm{pK}_{\mathrm{A}}+\frac{1}{2} \log k_{d}+\frac{1}{2} \log \tau-\log 1.12
$$

であた兄られ， $\mathrm{pK}^{\prime}$ は $\mathrm{pK}_{\mathrm{A}}$ より一般に大きく なり，乙れから $k_{d}$ ，したがつてまた $k_{r}$ が求め られる， $\mathrm{A}^{-} \rightarrow \mathrm{AH}$ の反応には $\left[\mathrm{H}_{3} \mathrm{O}^{+}\right]$の外， 緩衝塩の酸, 水分子等による〔 $\mathrm{H}^{+} 〕$ 附加反応を 考慮に入れる必要があるが，乙の場合もてれら の Proton donor 及び acceptor の濃度が一定 の条件下で実験を行えば，同様にして（I）の 機構を仮定するてとが出来る ${ }^{24)}$ 。些験絬果では 緩衝塩洪度わ゙ある程度以上ならば，その䟴度に 関せず $\bar{\imath}_{l}$ は同一 $\mathrm{pH}$ ではほぼ一定であり ${ }^{29,54)}$ K. Wiesner 等 ${ }^{5}$ ) の更に定量的な研究によると 少くとも酸性側では一般に上にあげた $\mathrm{H}_{3} \mathrm{O}^{+}$に よる再結合反応が非解離分子生成の主な反忘と してよいと結論される.Anion と水和したProton との再結合反応は Eigen 等その他によつ $\tau^{56,57)}$ 超音波吸收，Wien 效果, Fluorezenz 测 定等を用いても研究されている。役等によると この反応は Schwab の機構58,29)

$$
\mathrm{A}^{-}+\mathrm{H}^{+} \rightleftharpoons\left[\mathrm{A}^{-} \cdot \mathrm{H}^{+}\right] \rightleftharpoons \mathrm{AH}
$$

で進み，第一段階ぶ律速反応であつて， $k_{r}$ は Debye の式59) で説明され，分子種によつて大 きく変化せず，水溶液中でほぼ $10^{10} \sim 10^{11}$ liter $\mathrm{mol}^{-1} \cdot \mathrm{sec}^{-1}$ 程度の值をとると云われている。 反 応電流から求めた值ににいての同種の考祭は,

Rüetschi ${ }^{54}$, Delahay ${ }^{51,60)}$ 等によつて行われ， 緩衝壏の酸の影響や電場の影響について論ぜら れている。実測值は文献 ${ }^{18)}$ にまとめられてい る. Wiesner ${ }^{55)}$ 等は Proton donor について解 離定数と速度定数との間に Brönsted の関係を みとめている。野等 ${ }^{62,63)}$ は例光ば $\alpha$-keto酸 の場合, 酸の解離反応の外にカルボニル基の水 和一脱水反応を同時に考虑に入れる必要を指摘 し, 実測值についての再検討の必要を強調して いる(機構 (VI) 参照). 無機化合物の例としては ヨード酸, ブローム酸がある ${ }^{66)}$.
一塩基陖の再結合反応速度測定への応用のも う一つの例は, 直接 Proton の補給速度を反応 電流として取出す方法である，Rüetschi等 ${ }^{48,64)}$ は Azoben の還元波高が

$$
\mathrm{AH} \rightleftharpoons \mathrm{A}^{-}+\mathrm{H}^{+}
$$

にもとづく Proton の補給反応速度によつて規 定される事実を利用して上の反応の速度定数を 求》た. Stackelberg 等 ${ }^{21)}$ は Amin 類の存在 による接解水素還元波の波高为同様（34）式で 規定されるととを利用して, その速度定数を求 めている. Proton 自身の還元波を利用した例 もある ${ }^{65)}$ 乙れ等の方法は対象となる酸自体が還 元されない場合にも適用される点，また小野63) の指摘からも除かれる点等からみて興味深い. てれ等の方法による実測值と Eigen 等による 值 ${ }^{56)}$ との一致は満足す心゙きものである。な扔

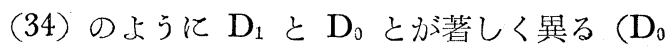

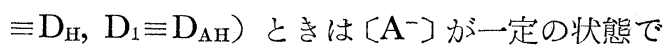
（31a）式を用いる必要がある。第 1 表に醋酸の 例を示す．用いられた $\mathrm{K}_{\mathrm{A}}$ によつて速度定数の 比は異る。誤差は $\pm 10 \%$ 程度 ${ }^{56)}$ あるいはそれ

\begin{tabular}{|c|c|c|}
\hline & $k_{d}\left(\sec ^{-1}\right)$ & $\begin{array}{c}k_{r}\left(\text { liter } \cdot \mathrm{mol}^{-1}\right. \\
\left.\cdot \mathrm{sec}^{-\mathbf{1}}\right)\end{array}$ \\
\hline Eigen, Schoen ${ }^{56)}\left(25^{\circ} \mathrm{C}\right)$ & $8 \cdot 105$ & $4.5 .10^{10}$ \\
\hline Stackelberg 等21) & $5.4 \cdot 10^{5}$ & $\left(3 \cdot 10^{10}\right)$ \\
\hline Rnenchi ${ }^{64)}$ & $2.1 \cdot 10^{5}$ & $4.4 \cdot 10^{10}$ \\
\hline
\end{tabular}
以上年あると思われる。

\section{第一表 醋酸の速度定数}

機構 (I）の適用例としてはアルデヒドのカ 一ボニル基の脱水反応ぶある。 Formaldehyde については詳細な研究が行われている ${ }^{67-71}$ 脱水 型か還元波を示し，

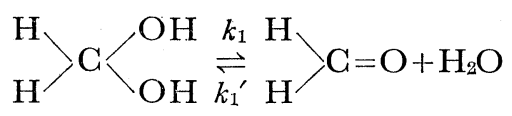

その波高は脱水反応による反応電流を示す $\left(\mathrm{K}_{h}\right.$ $=k_{1}{ }^{\prime} / k_{1} \sim 10^{4}$ でほぼ完全に水和している $)^{68)}$.

Borate の緩衝液中での脱水反忘速度定数は

$$
k_{1}=k_{0}+k_{\mathrm{HBO}_{3}}\left[\mathrm{H}_{2} \mathrm{BO}_{3}^{-}\right]+k_{\mathrm{OH}}\left[\mathrm{OH}^{-}\right]
$$

で示され (塩基触媒反応), Brdick 等は夫々に 対し $k_{0} / \mathrm{K}_{1}=1.5 \cdot 10^{-5}, k_{\mathrm{OH}} / \mathrm{K}_{1}=0.58, k_{\mathrm{H}_{2} \mathrm{BO}_{3}} / \mathrm{K}_{1}$ 
$=13 \cdot 10^{-4}\left(\mathrm{sec}^{-1}\right)$ なる值をあたえている ${ }^{69)}$ 。 の問題は更に非緩衝溶液中にまで研究が進めら れている ${ }^{69,70)}$ が（36)式の立場による笽密な理 論式との一致はよくない" ${ }^{71)}$ 。 ての不一致の点に ついての考察も進められたが70)，機構に関して はな打疑問があるようである ${ }^{72)}$. Acetaldehyde 等についても反応電流の現象が諗められてい る ${ }^{68)}$. カーボニル基の還元波としてはまた $\alpha$ -keto 酸の強酸性側に打ける反応電流 ${ }^{62,63)}$, 共䡉 した Diketone 及び Triktone のそれ46)等が報 告されている。乙れと関連したものに Aldose の環型の開環反応，また重要な反応電流として 金属イオンの錯塩等があるが，てれらについて は後述する.（I）に示した機構はもつとも簡単 な場合であり，一般的には以下に述べるような 機構から出発して検討するのが安全であろう。

2. 松田等 ${ }^{27)}$ は Koutecky の近似法を一般 化して

$$
\begin{gathered}
\mathrm{A}_{n} \leftrightharpoons \mathrm{A}_{n-1} \cdots \cdots \mathrm{A}_{3} \rightleftharpoons \mathrm{A}_{2} \rightleftharpoons \mathrm{A}_{1} \rightleftharpoons \mathrm{O} \\
\mathrm{B}_{m} \rightleftharpoons \mathrm{B}_{m-1} \cdots \cdots \mathrm{B}_{3} \rightleftharpoons \mathrm{B}_{2} \rightleftharpoons \mathrm{B}_{1} \rightleftharpoons \\
\mathrm{O} x \stackrel{n e}{\longrightarrow} \mathrm{Red}
\end{gathered}
$$

の晹合各化学㮔の拡散係数が等しくDとして一 般的な計算法を示した。 こてで A 及び B は共に electroinactive form である。それによると （19）の条件がみたされ，各反応について（31） 式の形が許されると仮定すれば，その限界電流 は

$$
\begin{gathered}
\bar{i}_{l}=\bar{i}_{c^{\prime}} \cdot \frac{1}{1+1.12\left(\lambda_{l} \sqrt{\tau}\right)^{-1}} \\
\bar{i}_{d}=607 n \sqrt{D} m^{2 / 3} \tau^{1 / j *} C
\end{gathered}
$$

即ち(20) 式であたえられる。 $\lambda_{2}$ の一般形は非 常に複雑である，以下比較的容易に求められ， また実用上も有用と思われる場合について二, 三計算した結果について記す。

(i)

$$
\mathrm{A}_{2} \underset{k_{2}^{\prime}}{\stackrel{k_{2}}{\rightleftharpoons}} \mathrm{A}_{1} \underset{k_{1}^{\prime}}{\stackrel{k_{1}}{\rightleftharpoons}} \mathrm{O} x \stackrel{n e}{\longrightarrow} \mathrm{Red}
$$

この場合 $\lambda_{2}$ は次式であたえられる。

$\frac{1}{\lambda_{l}}=\frac{\mathrm{K}_{1}\left(1+\mathrm{K}_{2}\right)}{\left(\sqrt{w_{1}}+\sqrt{w_{2}}\right)}\left\{1+\frac{1}{\sqrt{w_{1} w_{2}}}\left(l_{2}+\frac{\mathrm{K}_{2}}{1+\mathrm{K}_{2}} k_{1}\right)\right\}$

$$
\begin{gathered}
w_{1}, w_{2}=\frac{1}{2}\left[\left(l_{1}+l_{2}\right) \pm \sqrt{\left(l_{1}-l_{2}\right)^{2}+4 k_{1} k_{2} \mathrm{~K}_{2}}\right] \\
l_{n}=k_{n}+k_{n}{ }^{\prime}, \mathrm{K}_{n}=k_{n}{ }^{\prime} / k_{n}, \quad(n=1,2)
\end{gathered}
$$

こてで $\mathrm{K}_{1}, \mathrm{~K}_{2}$ が共に 1 亿くらべて大きいとす ると， $\lambda_{l}$ は簡単になつて

$$
\lambda_{l}=\frac{\sqrt{l_{1}}+\sqrt{l_{2}}}{\mathrm{~K}_{1} \mathrm{~K}_{2}}\left\{1-\frac{l_{2}+k_{1}}{\sqrt{l_{1} l_{2}}}\right\}^{-1} \mathrm{~K}_{1}, \mathrm{~K}_{2} \gg 1
$$

更に

$$
\begin{aligned}
& l_{2} \gg l_{1}: \lambda_{l} \sim \frac{\sqrt{k_{1}}}{\mathrm{~K}_{1} \mathrm{~K}_{2}} \\
& l_{1} \gg l_{2}: \lambda_{l} \sim \frac{\sqrt{k_{2}^{\prime}}}{\mathrm{K}_{2}}\left(\sqrt{\frac{l_{2}}{l_{1}}} \mathrm{~K}_{1} \ll 1\right)
\end{aligned}
$$

(37b, 37c) 式の意味は $\mathrm{K}_{1}, \mathrm{~K}_{2} \gg \mathrm{I}$ の条件下で 夫々（1）あるいは（2）の反応が律速段階であ ると考えれば，（I）の機構による $\lambda_{2}$ の表現 ((20) 式) から $\left(D_{1}=D_{2}=D_{0}\right)$ 明膫である.

(III) の機構についてはすでに Koutecky が $D_{1} \neq D_{2} \neq D_{o}$ の場合について解を与えている ${ }^{73)}$.

（III）の機構は二塩基有機酸の反応電流につい て多数の適用例が見出されている。 (Maleic, Citraconic, Fumaric ${ }^{73,74)}$, Oxalic ${ }^{75)}$, Phthalic, Monobenzyl phthalic ${ }^{76)}$, Ghinolinic, Cinchomeronic $^{77)}$ acids).

（ii）錯塩等の場合には更に多数の反忘種を 考慮に入れる必要があると思われる。その場合 ある一つの反応が全化学反応に対して律速的で あるとし，他の反応については部分平衡が成立 つていると考える方法は実用上にも意味がある と考えられる。たとえば

$$
\begin{aligned}
\mathrm{A}_{7} \stackrel{\mathrm{K}_{7}}{\rightleftharpoons} \mathrm{A}_{6} \stackrel{\mathrm{K}_{6}}{\rightleftharpoons} \mathrm{A}_{5} \underset{\mathrm{K}_{5}}{\stackrel{\mathrm{K}_{5}}{\rightleftharpoons} \underset{k_{4}^{\prime}}{\stackrel{k_{4}}{\rightleftharpoons}} \mathrm{A}_{3}} \\
\stackrel{\mathrm{K}_{3}}{\rightleftharpoons} \mathrm{A}_{2} \stackrel{\mathrm{K}_{2}}{\rightleftharpoons} \mathrm{A}_{1} \stackrel{\mathrm{K}_{1}}{\rightleftharpoons} \mathrm{O} x \stackrel{n e}{\longrightarrow} \text { Red }
\end{aligned}
$$

で $\mathrm{A}_{4} \rightleftharpoons \mathrm{A}_{3}$ が律速的であるとすると，その限界 電流は (20) 式と

$$
\begin{aligned}
& \lambda_{l}=\frac{\sqrt{k_{4} / \mathrm{K}_{f}+k_{4}^{\prime} / \mathrm{K}_{b}}}{\mathrm{~K}_{4} \cdot \mathrm{K}_{f} / \mathrm{K}_{b}} \\
& \mathrm{~K}_{f}=\left(1+\mathrm{K}_{5}+\mathrm{K}_{5} \mathrm{~K}_{6}+\mathrm{K}_{5} \mathrm{~K}_{6} \mathrm{~K}_{7}\right) \\
& \mathrm{K}_{b}=\left(1+\frac{1}{\mathrm{~K}_{3}}+\frac{1}{\mathrm{~K}_{3} \cdot \mathrm{K}_{2}}+\frac{1}{\mathrm{~K}_{3} \cdot \mathrm{K}_{2} \cdot \mathrm{K}_{1}}\right)
\end{aligned}
$$

であたえられる、反応種が更に增加した時の $\mathbf{K}_{f}$ 及び $\mathrm{K}$ は（38b）式から容易に類推されるで 


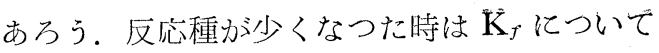
は順次 $\mathrm{K}_{7}=0, \mathrm{~K}_{6}=0$ 等と初き， $\mathrm{K}_{3}$ では順次 $1 / \mathrm{K}_{1}=0,1 / \mathrm{K}_{2}=0$ 等と拮けばよい. ( $\left.37 \mathrm{~b}, \mathrm{c}\right)$ は （38）の特別な場合として親办れる（33）式を 仮定した場合も第一段階が律速反応であつて，

Association した分子の量が $[\mathrm{AH}]$ にくらべて 充分小さいと扣くと機構（I）か邀用出来ると とが示される。

錯塩の反応電流についての報告も多い. (EDTA-錯篮 ${ }^{35,81,79 b)}$ ，シアン錯塭 ${ }^{78}$, NTA-錯 塩 $79,79 a)$ グリシン錯塩 ${ }^{800}$ ).

(iii)

$$
\mathrm{A}_{1} \underset{k_{1}}{\stackrel{k_{1}}{\rightleftharpoons}} \mathrm{O} x \underset{\substack{\downarrow \\ \text { Red }}}{\stackrel{k_{2}}{\rightleftharpoons}} \mathrm{B}_{1}
$$

Aldose 及び Ketose の反応電流は環型の糖 がアルデヒド型になる反応によるものとして， Wiesner ${ }^{19)}$ により最初にとりあげられた。 Delahay ${ }^{91)}$ にる研究もある. Los 等 ${ }^{82)}$ はGlucose の反応電流を詳細に検討し, Aldehyd 型 $(\mathrm{O} x)$ への補給は $\boldsymbol{\alpha}$-型 $\left(\mathrm{A}_{1}\right)$ と $\boldsymbol{\beta}$-型 $\left(\mathrm{B}_{1}\right)$ とから補 結されるととを確め, 溶液内に打ける Mutarotation も (V) の機構で進むとして, 上の $k_{1} \sim$ $k_{2}^{\prime}$ の反忘速度定数を求め, またその值が緩衝 塩の濃度に対し一次関係にあることを見出し た。 その際彼等は前節 2 で述べた Wiesner の考 えにしたがつつて反応層の厚さとして

$$
\mu=\sqrt{D /\left(k_{1}^{\prime}+k_{2}^{\prime}\right)}
$$

を用い， $\left(28^{\prime}\right)$ 式を用いて $\bar{i}_{l} / \bar{i}_{d} \ll 1$ の場合

$$
\overline{\boldsymbol{\imath}}_{k}=n \mathrm{~F} \bar{q} \cdot\left(k_{1} \cdot \mu \cdot * C_{1}+k_{2} \cdot \mu^{*} C_{2}\right)
$$

を導いた（V)の機構に対する理論式は(20)式 の $\lambda_{l}$ そ対して $\mathrm{K}_{1}, \mathrm{~K}_{2} \gg 1$ の場合

$$
\begin{aligned}
\lambda_{l}= & \sqrt{\overline{k_{1}{ }^{\prime}+k_{2}^{\prime}}} \cdot\left\{\mathrm{K}_{1}\left(1+\sqrt{\frac{k_{2}}{k_{1}}} \frac{1}{\mathrm{~K}_{1}+\mathrm{K}_{2}}\right)\right. \\
& \left.+\mathrm{K}_{2}\left(1+\sqrt{\frac{k_{1}}{k_{2}} \frac{1}{\mathrm{~K}_{1}+\mathrm{K}_{2}}}\right)\right\}^{-1} \quad(41
\end{aligned}
$$

となり, $k_{1} / k_{2} \sim 1$ の湯合に

$$
\lambda_{l}=\sqrt{\overline{k_{1}^{\prime}+k_{2}^{\prime}}} /\left(\mathrm{K}_{1}+\mathrm{K}_{2}\right)
$$

が導汃れ， $\overline{\boldsymbol{i}}_{l} / \boldsymbol{i}_{d} \ll 1$ の場合 40 式 $\left(* C_{1} /{ }^{*} C_{2}=\right.$ $\left.\mathrm{K}_{1} / \mathrm{K}_{2},{ }^{*} C={ }^{*} C_{1}+{ }^{*} C_{2}\right)$ 亿帰するととが示され る ${ }^{34)}$ (4lb) 式はまた Eucken の方法によつて
も得られる ${ }^{34)}$ 。最近 Paldus 等もこの問題を祣 密に取扱つた ${ }^{83)}$. Glucose の反応電流について は更に塚本 ${ }^{84)}$ とつて詳細に検討されているぶ 一般に（V)よりも更に復雑な機構が推量され るようである。

$(38 ， 38 \mathrm{~b})$. 式をみれば, $\mathrm{K}_{4} \cdot \mathrm{K}_{5} / \mathrm{K}_{b} \gg \mathrm{l}$ の場

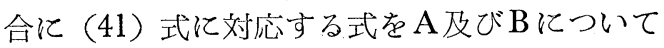
(IV)の機構を考えた時にまで拡張することは容 易である.（(41) 式で $\mathrm{K}_{1}, \mathrm{~K}_{2}$ に対し $\mathrm{K}_{4} \cdot \mathrm{K}_{5} /$ $\mathrm{K}_{b}$ にあたる式を， $k_{1}^{\prime}, k_{2}^{\prime}$ に対して $k_{4}^{\prime} / \mathrm{K}_{b}$ にあ たる式をそれぞれ入れればよい).

3. 前述 1 でもふれたように，小野等 ${ }^{62)}$ は特 に有機化合物では一つの分子の内に反応電流を 示す可能性のある基が二ケある場合が多いとと を指摘した。このような機構はたとえば

$$
\begin{aligned}
& \mathrm{A}_{2} \underset{k_{4}}{\stackrel{k_{2}}{\rightleftharpoons} k_{k_{2}^{\prime}}} \mathrm{A}_{2_{1}^{\prime}}{ }_{k_{1}^{\prime}} \mathrm{B}_{1} \underset{k_{3}}{\stackrel{k_{3}}{\rightleftharpoons}} \mathrm{O} x \stackrel{n e}{\longrightarrow} \text { Red. }
\end{aligned}
$$

で示される，乙の機構に対する解も (19) の条 件下で同様（20）式で解があたえられるが， の表式は非常に複雑になる85)。しかしたとえば

$$
l_{2} \gg l_{1}, l_{3} \gg l_{4}
$$

等の時は簡単になり,

$$
\lambda_{l}=\frac{\sqrt{\bar{l}_{2}^{\prime}+l_{4}^{\prime}}}{\mathrm{K}}
$$

$$
\left.\begin{array}{l}
l_{2}^{\prime}=\frac{\mathrm{K}_{2}}{1+\mathrm{K}_{2}} \cdot k_{4}+\frac{1}{1+\mathrm{K}_{2}} \cdot k_{1} \\
l_{4}^{\prime}=\frac{\mathrm{K}_{3}}{1+\mathrm{K}_{3}} k_{4}^{\prime}+\frac{1}{1+\mathrm{K}_{3}} k_{1}^{\prime} \\
\mathrm{K}=l_{2}^{\prime} / l_{4}^{\prime}
\end{array}\right\}
$$

であたえられる。

4. 二段階還元をうける化合物では次のよう な機構の考えられるものがある ${ }^{86,87)}$.

$$
\mathrm{O} x_{1} \stackrel{n_{1} e}{\longrightarrow} \mathrm{A}_{1} \underset{k_{1}^{\prime}}{\stackrel{k_{1}}{\rightleftharpoons}} \mathrm{O} x_{2} \stackrel{n_{2} e}{\longrightarrow} \mathrm{Red}
$$

この場合の限界電流は同様にして（19）式を仮 定すれば

$$
\bar{i}_{l}=\bar{i}_{d 1}\left(1+\frac{n_{2}}{n_{1}} \frac{1}{1+1.12\left(\lambda_{l} \sqrt{\tau}\right)^{-1}}\right)
$$

であたえられる88)。 $\bar{i}_{d 1}$ は $\mathrm{O} x_{1} \rightarrow \mathrm{A}_{1}$ による限 界拡散電流で， $\lambda_{l}$ は 


$$
\lambda_{l}=\frac{\sqrt{l_{1}}}{\mathrm{~K}_{1}}
$$

であたえられる.（43）式は p-Nitrosphenol の 還元波 ${ }^{86,87,89)}$ について適用され， $\mathrm{HO} \cdot \mathrm{G}_{6} \mathrm{H}_{4}$ ・ $\mathrm{NHOH}$ の脱水反応速度定数として $k_{1} / \mathrm{K}_{1}=$ $95+0.01\left[\mathrm{H}^{+}\right]^{-1} \cdot 10^{-4} \mathrm{sec}^{-1}$ が得られた $^{88)} \cdot \mathrm{A}_{1}$ と $\mathrm{O} x$ との間に (IV) の機構を考える場合も (38) 式と同様にして $\lambda_{l}$ が求められる.

5.

$$
\begin{gathered}
\mathrm{A}_{1} \underset{k_{1}^{\prime}}{\stackrel{k_{1}}{\rightleftharpoons}} 2 \mathrm{O} x \\
\mathrm{O} x \stackrel{n e}{\longrightarrow} \mathrm{Red} .
\end{gathered}
$$

Dimer がMonomerに変化する反応による反 応電流である， $l_{1} t$ が大きく, 平衡が $\mathrm{A}_{1}$ の方に かたよつている $\left(\mathrm{K}_{1} \gg 1\right)$ 場合については $\mathrm{Kou}$ tecky 等の解がある ${ }^{90)}$.

$$
\begin{aligned}
& \bar{i}_{l}=\bar{i}_{d} \cdot \mathrm{F}\left(\lambda_{l} \sqrt{\tau}\right) \\
& \lambda_{l}=\left[k_{1} / V^{*} C_{1} \cdot \mathrm{K}_{1}\right]^{1 / 2}
\end{aligned}
$$

で示されるが $\mathrm{F}\left(\lambda_{e} \sqrt{\tau}\right)$ は表であたえられてい る，反応層を用いる解についても考察されてい る.（VIII）の機構はアルカリ性溶液中での $\mathrm{Di}-$ thionit の波で認められると云われている ${ }^{90)}$.

\section{§緩衝液について}

反応電流の研究に执いてのみならず，ポーラ ログラフ法では緩衝塩溶液が広く用いられてい

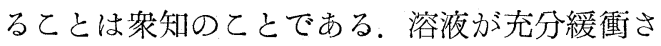
れているとみなしうるための条件について，乙 てで，少し実量的な考察をしてみたい.

充分に緩衝されていない溶液でのポーラログ ラフ波の挙動については Rüetschi 等 ${ }^{54,91)}$ の詳 しい検討があり, その特別の場合として, 酸の 解離速度の測定への応用については先にの心゙ た ${ }^{64)}$.かんたんのためいまただ一種の一塩基性 緩㣫塩 $\left(\mathrm{B}^{-}, \mathrm{BH}\right)$ 存在下の反応を考元，

$$
\begin{aligned}
& \mathrm{BH} \rightleftharpoons \mathrm{H}^{+}+\mathrm{B}^{-} \\
& \mathrm{O} x+m \mathrm{H}^{+} \stackrel{n e}{\rightleftharpoons} \mathrm{Red}
\end{aligned}
$$

の反応により水素イオン污消費されると考えよ う. $\mathrm{H}^{+}$の補給が上の反応によつてのみ起ると 考えると.

$$
\begin{aligned}
m & \cdot \frac{D_{o}}{\delta_{o}}\left({ }^{*} C_{0}-{ }^{0} C_{0}\right)=\frac{D_{B H}}{\delta_{B H}}\left(C_{B H}-{ }^{0} C_{B H}\right) \\
& =\frac{D_{B}}{\delta_{B}}\left({ }^{0} C_{B}-C_{B}\right)
\end{aligned}
$$

が成立つ. 先ず緩衝塩の再結合及び解離反応が 充分速いと仮定すると, 界面での $\mathrm{pH}$ は

$$
{ }^{\circ} \mathrm{pH}=\mathrm{pK}+\log ^{{ }^{\circ}{ }^{\circ} C_{B}}
$$

であるから, 界面での緩衝塩の濃度変化 $\Delta C_{B}=$ $C_{B H}-{ }^{0} C_{B H}={ }^{0} C_{B}-{ }^{*} C_{B}\left(D_{B}=D_{R H}=D_{o}\right.$ とする $)$ による $\mathrm{pH}$ の変化 $\Delta \mathrm{pH}$ は

$$
\Delta^{\circ} \mathrm{pH}=\frac{1}{\beta} \cdot \Delta C_{B}=\frac{1}{\beta_{\mathrm{M}}} \cdot \frac{\Delta C_{\underline{B}}}{C}
$$

であたえられる。乙こで $\beta$ は用いた緩衙液の緩 衝能， $\beta_{M}$ は分子緩衝能， $C={ }^{*} C_{B}+C_{B H}$ で, $\beta_{\mathrm{M}}$ は次式であたえられる ${ }^{92,93)}$.

$$
\beta_{\mathrm{M}}=\frac{2.30 \mathrm{~K}\left[\mathrm{H}^{+}\right]}{\left(\mathrm{K}+\left[\mathrm{H}^{+}\right]\right)^{2}}
$$

$\mathrm{K}$ は $\mathrm{BH}$ の解離定数, $\left[\mathrm{H}^{+}\right]$は水素イオン瀑度 である. (46) 式から $\Delta C_{B}=m \cdot \Delta C_{0}=m\left(C_{0}-\right.$ ${ }^{0} C_{0}$ ) であるから，(48) 式から

$$
\Delta^{\circ} \mathrm{pH}=\frac{1}{\beta_{M}} \cdot \frac{\Delta C_{0}}{C} \cdot m
$$

したがつてたとえば限界拡散電流の籁囲（ $\Delta C_{o}$ $={ }^{*} C_{0}$ ) まで界面の $\Delta \mathrm{pH}$ が 0.1 以下であるた めの条件は

$$
\frac{{ }^{*} C_{o}}{C}<\frac{0.1}{m} \cdot \beta_{\mathrm{M}}
$$

であたえられる，注意すべきは $\beta_{\mathrm{M}}$ は $\left[\mathrm{H}^{+}\right]=$ $\mathrm{K}$ で最大 (0.575) 值をとり, $\mathrm{pH}$ が $\mathrm{pK}$ から ずれると共に急激に減少することである。たと えば $\mathrm{pH}=\mathrm{pK} \pm 1$ で $m=2$ とすると ${ }^{*} C_{o} / C<$ 0.0096 となる。 $\beta_{M}$ は各緩衝塩の種類によつて あたえられる ${ }^{93)}$. (50) 式を一般化すると

$$
\begin{aligned}
& \Delta^{\circ} \mathrm{pH}=\frac{\Delta^{0}\left[\mathrm{H}^{+}\right]}{{ }^{0}\left[\mathrm{H}^{+}\right]}=\frac{\Delta \mathrm{C}_{0}}{\beta} \cdot m \\
& \beta=2.30\left[\left[\mathrm{H}^{+}\right]+\left[\mathrm{OH}^{-}\right]\right] \\
& +\left[\beta_{\mathrm{M} 1} \cdot \mathrm{C}_{1}+\beta_{\mathrm{M} 2} \cdot \mathrm{C}_{2}+\cdots \cdots\right]
\end{aligned}
$$

を得る。ただし $(52,53)$ 式は各化学種とも $D$ を 同一と扔いた，D无大きい緩衝堛程ポーラログ ラフ的な緩衝能は大きい、したがつて上の式で は $\left[\mathrm{H}^{+}\right]$及び $\left[\mathrm{OH}^{-}\right]$にいては少し小さめに 出ている。 
$\mathrm{BH}$ 等の解離速度か問題になるとかなり複雑 になるが，反応酋の考え方を用いて次のように 見積ることが出来る ${ }^{94)}$. 今反応層の厚さを $\mu$ と 打くと

$$
=\underset{f_{o} m}{=} \cdot \frac{D_{o}}{\delta_{o}}\left({ }^{*} C_{o}-{ }^{0} C_{o}\right)=\mu k_{d}{ }^{0} C_{B H}-\mu k_{r}{ }^{0} C_{B} \cdot{ }^{\circ}\left[\mathrm{H}^{+}\right]
$$

であるから，

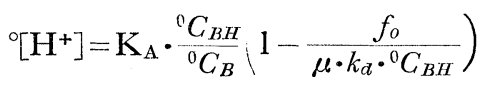

を得る。 $\mathrm{K}^{0} C_{B H} /{ }^{0} C_{B}$ は上で考察した水素イオン 浱度に対応するから，在辺第 2 項分だけ更に [ $\left[\mathrm{H}^{+}\right]$は変化することになる。第 2 項が充分小 さければ緩衝能力は $(52,53)$ 式であたえられ る. 第 2 項 $\left(\Delta\left[\mathrm{H}^{+}\right] /\left[\mathrm{H}^{+}\right]\right)_{k}$ が 1 亿近づくと

$$
f_{0}=\mu k_{d}^{0} C_{B \boldsymbol{H}}
$$

即ち $\mathrm{BH}$ の解離速度測定の条件 ${ }^{64)}$ 少導かれる。 $\mu$ は $\sqrt{D} / \sqrt{k_{a}+k,\left[{ }^{[} C_{B}\right]}$ の程度である。 $\mathrm{pH} \sim$ $\mathrm{pK}$ で限界桩撒電流の附近での第 2 項は(51)式 から ${ }^{\circ} C_{B H} \approx * C_{B H} \approx \frac{1}{2} C$ であるから，

$$
\left[\begin{array}{c}
\Delta^{0}\left[\mathrm{H}^{+}\right] \\
{ }^{\circ}\left[\mathrm{H}^{+}\right]
\end{array}\right]_{k} \sim \frac{2^{*} C_{o}}{{ }^{*} C} \cdot \frac{m}{\sqrt{k_{d} \cdot \tau}}
$$

となる. こてで近似的に $D_{o} / \boldsymbol{\delta}_{o}=\sqrt{D} / \sqrt{\tau}, \mu=$ $\sqrt{D} / \sqrt{k_{a}}$ とした. (51)汃ら $m^{*} C_{o} / C \sim 0.01$ 程度 であるから，第 2 項方無視されうるには $\sqrt{k^{\bullet} \tau}$ が 1 程度より小さくなる必要がある. $\mathrm{pK}$ の小 さいものでは一般にての条件はみたされる（第 1 表参照). pK の大きい例としては Borate で $k_{d}=1.3 \cdot 10^{3} \mathrm{sec}^{-1}$ という值が得られている ${ }^{65)}$. $k_{r}$ が $10^{11} \cdot$ liter $\cdot \mathrm{mol}^{-1} \cdot \mathrm{sec}^{-1}$ 程度 ${ }^{56)}$ とすると $\mathrm{pK}<11$ の緩衝塩で上の条件がみたされること になるが， $\mathrm{pH}=12$ 附近からは $\left[\mathrm{OH}^{-}\right]$による 緩衝能ふ泏て来る，以上のような大体の見積わ らいつて電流值に対応する $m^{*} C_{0}$ が* $C$ に対し て 1100 程度ならば， $\mathrm{pH}=\mathrm{pK} \pm 1$ の簌国の緩 衝液でポーラログラフ的な緩衝能はほぼ満足さ れる程度にあると云つてよさそうである。

[附記]以上で先行反応には反応電流の紹介を 終 る、著者の烃力が不足のため，引用すべさ報告でな打 落ちているものも多く，また不楜当な紹介や考察もあ るかと思う。これらの点について御教示をいたら゙けば 非常に有難いと思つている。

\section{交献}

1) 神原：電化 21，392，439（1953）

2) P. Delahay: New Instrumental Methods in Electrochemistry, Interscience Publ., New York (1954)

3) W. Hans : Z. Elektrochem. 59, 623 (1955)

4）舘，千田：化学の領域 9, 627 (1955)

5) 神原：本誌 4, 28 (1956)，5，85(1957)

6) 高橋 : 本誌 4, 54 (1956)

7) 千田：本誌 4, 88 (1956)

8) M. von Stackelberg: 本誌 6, 14 (1958)

9) A. Sevcik : Collection 13, 349 (1948)

10）神原，舘：Bull. Chem. Soc. Japan 25, 135 (1952)

11) D. Ilkovic, Collection

12）神原，涻：電化 18，143，189，258（1950）

13）舘，千田：電化 21，573 (1953)

14）高橋，舘：ポーラログラフ討論会 1956-11月 （東京）

15）麻田：学位論文 京大工学部 1958-3月，岡田等， 電化東京大会 1958- 4 月

16) K. Wiesner : Z. Elektrochem., 49, 164 (1943)

17）杉野，林：日化誌 65，164（1944）

18) R. Brdicka : Collection, 19, SII (1954)

19) K. Wiesner : ibid., 12, 64 (1947)

20）杉野等：電解酸化還元，電化便覧 P. 708 (1953)

21) M. von Stackelberg, W. Nürnberg : 本誌，6, 14 (1958)

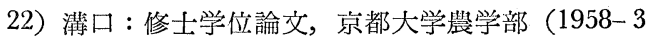

月） M. von Stackelberg, 私信

23) V. Vojir : Collection, 18, 629 (1953)

24) J. Koutecky, R. Brdicka : ibid., 12, 337 (1947)

25) 永田：本誌 5, 8 (1957)

26) H. Gerischer : Angew. Chem., 68, 20 (1956)

27）松田，綾部：Bull. Chem. Soc. Japan，29，134 (1956)，ポーラログラフ討論会 1957-10月（京 都), 1958-9 月（仙台）

28）宇永：本誌 4, 19 (1956)

29) V. Hanus : Proceeding 1. Intern. Congress (1951) p. 811.

30) J. Koutecky : Collection, 18, 597 (1953)

31) J. Cizek, J. Koutecky : ibid., 20, 930 (1955)

32）松田，綾部：Bull. Chem. Soc. Japan 28， 422 (1955)

33) K. Wiesner : Anal. Chem. 27, 1712 (1955) 
34) 千甘，舘：ポーラログラフ討論会 1956-11月 (東宗)

35）田中，玉虫，児玉 : Z. physik。Chem. N.F., 14， 10 (1958)

田中，大岩，児玉 : Anal Chem., 28, 1555 (1956)

36) R. Brdicka, K. Wisner : Collection 12, 138 (1947)

37) K. Wiesner : Chem. listy, 41, 6 (1947)

38) W. Jost : Diffusion, Academic Press, New York (1952)

39) A. Eucken : Z. physik. Chem., 64, 564 (1908)

40) H. Gerischer, R.J. Vetter : Z. physk. Chem. 197, 92 (1951) ; K.J. Vetter, : Z. Elektrochem., 56, 931 (1952)

41) K.-H. Henke, W. Hans : Z. Elektrochem. 57, 591 (1953)

42) D.M.H. Kern : J.A.C.S., 75, 2473 (1953)

43) J. Koutecky, J. Cizek : Collection, 21, 836 (1956)

44) Glasstone, Laidler and Eyring : The Theory of Rate Processes, McGraw-Hill, New York (1941)

45）永田, 舘: Bull. Chem. Soc. Japan, 27, 290 (1954)

46) 小野，高木，和佐 : Bull. Chem. Soc. Japan, 31, 356 (1958)

47）舘，永田，十河 : 農化誌 29，541（1955）

48) P. Rüetschi : Z. physik. Chem. N.F., 5, 323 (1955)

49) J. Koutecky : Proceedings 1. Intern. Congress (1951) Part 1. p. 826

50) J. Koutecky : Collection, 18, 183 (1953)

51) J. Koutecky, : ibid., 19, 857 (1954)

52) H.H.G. Jellinek, J.R. Orwin : J. Phys. Chem., 58, 168 (1954)

53) W. Hans, K.-H. Henke, : Z. Elektrochem., 57, 595 (1953)

54) P. Rüetschi, G. Trümpler : Helv. Chim. Acta, 35, 1957 (1952)

55) K. Wiesner, M. Wheatley, J.M. Los : J.A.C.S. 76, 4858 (1954)

56) M. Eigen : Z. physik. Chem. N.F., 1, 176 (1954) M. Eigen, J. Schoen : ibid., 3, 126 (1955)

57) A. Weller : ibid., 3, 238 (1955)

58) G.M. Schwab : Z. physik. Chem., A183, 250 (1939)

59) P. Debye : Trans. electrochem. Soc., 82, 265 (1942)
60) P. Delahay, T.J. Adams : J.A.C.S. 74, 1437 (1952)

61) P. Delahay, W. Vielstich : Technical Report 22, (1955)

62) 小野：生化学とポーラログラフイー p. VUI-9 (1956)

63）小野，高木，和佳：日化符 9 年会 (1956)

64) P. Rüetschi, W. Vielstich : Z. physik. Chem., N.F., 4, 124 (1955)

65) J.Kuta : Collection, 22, 1411 (1957)

66) V. Cermak : ibid., 21, 1344 (1956)

67) K. Vesely, R. Brdicka : ibid., 12, 313 (1947)

68) R. Bieber, G. Trümpler : Helv. Chim. Acta, 30, 706, 2000 (1947) ; 31, 5 1948)

69) R. Brdicka : Collection, 20, 387 (1955)

70) R. Brdicka : Z. Elektrochem., 59, 787 (1955)

71) J. Koutecky : Collection, 21, 652 (1956)

72) 高木 : 私信

73) J. Koutecky : Collection, 19, 1093 (1954)

74) V. Hanus, R. Brdicka, : Chem. listy, 44, 291 (1950) : Chimia, 1, 28 (1951)

75) J. Kuta : Collection, 21, 697 (1956)

76) A. Ryvolova, V. Hanus : ibid., 21, 853 (1956)

77) J. Volke : ibid., 22, 1777 (1957)

78) J. Koryta : Z. Elektrochem., 61, 423 (1957)

79) J. Koryta : Proceedings 1. Intern. Congress (1951) Part 1, p. 798

79a) R.W. Schmid, C.N. Reilley : J.A.C.S., 80, 2101 (1958)

79b) J. Koryta, I. Kössler : Collection, 15, 241 (1950)

80) M. Kopanica, J. Dolezal, : Collection, 23, 50 (1958)

81) P. Delahay, J.E. Strasner : J.A.C.S., 74, 893 (1952)

82) J.M. Los, K. Wiesner : ibid., 74, 6346 (1952) J.M. Los, L.B. Simpson, K. Wiesner : ibid., 78, 1564 (1957)

83) J. Paldus, J. Koutecky : Collection, 23, 376 (1958)

84）塚本：ポーラログラフ討論会 1957-10月（京都）

85）著者等: 未発表

86) 鈴木 : 電化誌 22, 112 (1954)

87) 鈴木 : Memoirs College Agriclture, Kyoto Univ, No. 67 (1954) 
88) 千田，舘：電化東京大会（1958-4月）

89) L. Holleck, R. Schindler : Z. Elektrochem., 60, 1138 (1956)

90) J. Koutecky, V. Hanus : Collection, 20, 124 (1955)

91) P. Rüetschi, G. Trümpler : Helv. Chim. Acta, 35, 1021, 1486 (1952)

92）石川：酸㙁基の理論，産業図青（1950）

93) R.G. Bates : Electrometric pH Determination,
John Wiley \& Sons. New York (1954)

94) P. Delahay : J.A.C.S•, 74, 3497 (1952)

95) J. Heyrovsky, M. Matyas : Collection, 16, 455 (1951)

96) J. Heyrovsky : ibid., 19, SII, 58 (1954)

97) R.W. Schmid, G.W. Reilley : J.A.G.S., 80, 2087 (1958)

98) K. Schwab : Z. Elektrochem., 61, 484 (1957)

\section{新刊紹介}

Modern Electroanalytical Methods, Ed. G. Charot, Elsevier Publ. Co., Amsterdam (1956) $182 \mathrm{pp}$.

阼年 7 月 23，24 日 Paris にて G. Charlot 教授の扎世話で開かれました「分析の新しい電 気化学的方法のシンポジウム」に扔ける報告集ぶ, Anal. Chim. Acta 18 (1958) No. 1-2 と して発刊されましたが，別に単行本としても上記書店から発売されています。（約 1300 円）. 内容は下記の通りです。

\section{CONTENTS}

\section{T.P. Hoar, Adress}

\section{I.M. Kolthoff, Introduction}

H.A. Laitinen and H.G. Gaur, Chronopotentiometry in fused lithium chloride-potassium chloride.

H.L.Kies, Ampérométrie avec deux électrodes indicatrices.

$R$. Gauguin, Potentiométrie à intensité constante.

A. Peter et J." Coursier, Courbes intensité-potentiel dans les échangeurs d'ions.

F. Cuta, Coulometric determinations.

R.D. Weaver and G.C. Whitnack, The millicoulometric method for n-values.

P.S. Tutundzic, Coulometrie und das Coulomb als universelle Urtitersubstanz.

P. Delahay and I. Trachtenberg, Adsorption kinetics and electrode processes.

D.I. Love, New techniques in radiochemical determinations using polarographic methods.

G. Mamantov, P. Papoff and P. Delahay, Anodic stripping voltammetry with mercury eletrode. Potentialstep and current-step methods.

I.M. Kolthoff and Y. Okinaka, Factors to be considered in quantitative polarography with the rotated dropping mercury electrode.

N. Tanaka, T. Koizumi, T. Murayama, M. Kosama, and Y. Sakuma, The use of the rotated dropping mercury electrode in polarographic analyses and amperometric titrations of micromolar solution.

$W$. Kemula et Z. Kublik, Application de la goutte pendante de mercure à la détermination de minimes quantités de différents ions.

M. Ishibashi and T. Fujinaga, Current scanning polarography at the dropping mercury electrode.

G.C. Barker, Square wave polarography and some related techniques.

R. Kalvoda, Oszillopolarographische Mikroanalyse.

H. Berg und K.H. König, Polarographische Untersuchungen cytostatischer Chinonderivate.

R. Pleticha, Polarogrophie und Oszillographie des Vitamins $\mathrm{B}_{\mathbf{1}}$ vom analytischen Standpunkt.

F. Oehme, Anwendungsmöglichkeiten der Hochfrequenzmesstechnik in der analytischen Chemie.

$Y$. Conseiller et J. Courteix, Titrimètre haute fréquence.

Utilisation pour les titrages en milieu anhydre.

V.S. Griffiths, Newer methods of determining electrolytic conductivity.

A. Schleicher, Neue Theorie der Elektrolyse und der Redoxydationen, 